Article

\title{
On the Role of Construction in Achieving the SDGs
}

Sherif Goubran

Individualized (INDI) Program, Concordia University, Montreal, H3G 1M8, Canada; Email: sherif.goubran@mail.concordia.ca

\section{G Open Access}

Received: 18 June 2019

Accepted: 29 October 2019

Published: 30 October 2019

Copyright $₫ 2019$ by the author(s). Licensee Hapres, London, United Kingdom. This is an open access article distributed under the terms and conditions of Creative Commons Attribution 4.0 International License.

\begin{abstract}
Construction and real estate have been central to the debates on sustainable development. However, the dominant definition of sustainability in construction and real estate remain centred on the environmental dimension. The 2030 Agenda and its Sustainable Development Goals (SDGs) offer new opportunities for the building sector to expand its focus. The available literature utilizes the existing green ratings, sustainability assessment tools and standards as the basis for investigating how construction and buildings can contribute to the 2030 Agenda for Sustainable Development. However, less focus was placed on exploring the broad intersection between the building sector, on the one hand, and the SDGs and their targets on the other. This paper uses a multistep methodology to analyze the potential role of construction and real estate in the 2030 Agenda. The paper identifies SDG targets that depend (directly or indirectly) on construction and real estate activities, and reveals that $17 \%$ of the SDG targets are directly dependent and $27 \%$ of the targets are indirectly dependent on these sectors' activities. The identified targets are analyzed and are found to be related to all 17 goals-with the largest contributions to SDGs 11, 6, and 7. The results of the analysis are mapped and illustrated in order to provide insights to academics, practitioners and governments. This research contributes to the literature on the implementation of the 2030 Agenda. It also exposes the synergistic possibilities, and the partnerships required, to make use of the potential role of construction and real estate in the implementation of the UN Agenda.
\end{abstract}

KEYWORDS: Sustainable Development Goals (SDGs); implementation; construction; real estate; target dependence; mapping

\section{INTRODUCTION}

Sustainable construction has been the focus of many publications in recent decades. The available literature tackles themes such as improving, analyzing or evaluating the sustainability of construction and building projects [1,2]. Other researchers have concentrated on measuring the negative impacts of construction projects and the real estate sector [3,4]. Common to these approaches is the focus on the environmental 
dimension [5-7]. If construction and real estate are to play a role in sustainable development, the building sector needs to work towards achieving the Sustainable Development Goals (SDGs) [8-12]. In the face of global change (in climate, markets, and demographics), the construction and real estate sectors have to align their approach with the SDGs and to expand their scope to dedicate equal attention to the agenda's five Ps: people, planet, prosperity, peace and partnerships [13,14].

Since the adoption of the 2030 Agenda, scholars and practitioners have been studying the SDGs, their possible implementation processes [15], the synergies and trade-offs between their goals and targets [16], as well as the means to improve reporting capacity on progress $[17,18]$. Researchers also used mapping methods to understand the relations and contradictions within the agenda and to propose methods for prioritization actions for achieving the goals [19-21]. Other scholars explored which of the goals are receiving the most attention from experts [22]. Another less common research direction aims at intersecting the activities of different economic sectors on the one hand and the SDGs and their targets on the other. Published sources focus on sectors such as energy or healthcare [23,24], but the literature pertaining to the construction sector has been rather limited. The available research focuses on where the existing environmental assessment criteria and the SDGs intersect [25,26], or on proposing general theoretical frameworks for considering the broader sustainability topics in building projects $[6,27,28]$. There are few sources that explore the comprehensive role construction activities and buildings play in the 2030 Agenda.

This paper aims to address this gap by exploring where construction, real estate activities, and buildings play a role, both directly and indirectly, in supporting the SDGs and their targets. It is the main hypothesis of this research that many of the agenda's targets depend on the activities of the construction and real estate sectors. Instead of using existing environmental standards, rating tools, and assessment systems, the paper focuses on where the targets of the UN agenda and construction and real estate activities intersect to determine their direct and indirect dependence [8]. The paper aims to identify how the building, construction and real estate sectors interact with the SDGs-a key component of the SDG sector road map proposed by the World Business Council for Sustainable Development (WBCSD) [29]. The first section of the paper presents a detailed description of the research design and the overall process used for mapping the roles of construction activities in the 2030 Agenda. In the background section, the paper provides an overview of the 2030 Agenda and its development process. The paper also discusses some current research trends regarding the SDGs, future projections related to the construction and real estate sectors, and the relevance of the 2030 Agenda to these economic sectors. The paper then presents the results of the analysis visually, discusses the implications of the findings and suggests future research directions. 


\section{METHODOLOGY}

There have been many debates on the definition of sustainability in the built environment, its components, and the means of assessment [9]. From the perspective of sustainable design analysis, the fact that the SDGs provide a globally accepted definition that is supported by local commitments for the next 10 years makes them a suitable organizing principle for current research on the topic of sustainable construction and real estate [13,14]. This is well justified since the agenda provides an expansive and practical definition of the development required to achieve sustainability on a global scale. By looking at the recent literature pertaining to the 2030 Agenda, it is clear that the interconnected nature of the SDGs and their targets present many synergetic possibilities [15,19]. By highlighting the direct and indirect dependence of the SDG targets on construction and real estate activities, institutions and organizations can capitalize on these synergies to better achieve the agenda's goals.

To achieve the objectives of this research, the first step focused on extracting relevant literature on the topic. This research uses the EBSCO Discovery Service (Discovery search) and Google Scholar for finding academic literature sources. Resources available through the United Nations and its affiliated organizations are also reviewed. Additionally, sources and reports from other prominent international organizations (such as The World Economic Forum and major consulting firms) are used to support the discussion. The literature found could be divided into two main categories: (1) sources that directly explore the relations between construction activities and the 2030 Agenda (including its goals and targets), and (2) sources that present mapping and/or analysis approaches to the SDGs and their targets. The collection aimed to identify the most relevant literature because available published sources already provide comprehensive records [15,22].

The second step in the research involved direct content analysis [30] for the 2030 Agenda in order to identify targets that depend on construction and real estate activities. In this paper, construction activities are considered to include constructing, maintaining or adapting structures (including residential, institutional or industrial facilities) and infrastructure (including transportation, water/sanitation, energy and telecommunication infrastructures). This is in line with Behm's definition of construction work:

"Construction work can involve building of new structures, which may include activities involved with subdividing land for sale as building sites or preparation of sites for new construction. Construction work also includes renovations involving additions, alterations, or maintenance and repair of buildings or engineering projects such as highways or utility systems." [31]

Real estate activities are considered in this paper to include buying, selling, developing, and managing buildings or land (for commercial, 
residential or industrial purposes). The targets were categorized as follows:

- Targets that are directly dependent on construction and real estate activities, which include:

(A) Targets that can be achieved mainly by construction and real estate activities. These include targets that call for building and upgrading facilities or infrastructures.

(B) Targets where construction and real estate activities play a significant role. These include targets that call for increased access to services or facilities.

- Targets that are indirectly dependent on construction and real estate activities, which include:

(C) Targets where construction and real estate activities are partially relevant. In this category, construction and real estate activities play a role in achieving the targets, among other economic, sociocultural, and political activities. This category includes targets that call for local economic growth, job creation or increasing the capacity for innovation and development.

(D) Targets where construction and real estate activities play a supportive role. In this category, construction and real estate activities are needed to support the economic, socio-cultural or political targets that need infrastructure and/or facilities to be updated/constructed to be realized. This category includes nonconstruction targets that call for enhanced collaboration and knowledge sharing or strengthening political or economic networks.

- Targets that are independent of construction and real estate activities.

Figure 1 presents the process of allocation among the 3 categories presented and illustrates the direct and indirect dependence conditions. For example, the process target 4.a (Build and upgrade education facilities that are child, disability and gender sensitive and provide safe, nonviolent, inclusive and effective learning environments for all) falls under category (A) because it can be directly achieved by construction activities-i.e., achieved by building and upgrading facilities. On the other hand, target 8.5 (By 2030, achieve full and productive employment and decent work for all women and men, including for young people and persons with disabilities, and equal pay for work of equal value) falls under category (D) because it cannot be achieved solely by construction activities but construction and real estate activities are potentially required in order to build or to upgrade facilities and infrastructure that are needed to create new employment opportunities and to accommodate people with disabilities. Finally, target 5.1 (End all forms of discrimination against all women and girls everywhere) requires a number of actions that are not related to construction or real estate activities (i.e., it is 
independent of construction and real estate activities). Table A1 in the Appendix describes the reason for allocation and presents the relevant references for each selected target. Sources that mention construction, real estate activities and urbanization were also used in the selection process; those include [14,19,23,25,26,32-40]. It is important to highlight that the direct (or indirect) dependence of a target on construction and real estate activities does not reduce the role of policies, regulations, and laws in attaining the agenda's objectives, and does not diminish the importance of other political, economic, social, financial and cultural activities needed to attain the specific target.

Given that no previous research explored the relationship between construction and real estate activities and the 2030 Agenda's individual targets in-depth, the available sources were used as follows:

- Sources dealing with construction and real estate activities:

1. For sources that mention individual SDG targets, these targets were identified as candidates for direct or indirect dependence.

2. For sources citing specific activities in relation to the goals (with no analysis of individual targets), the information was used to identify relevant targets within the goals mentioned.

- Sources dealing with other sectors or sources that study the agenda in its entirety:

1. For sources that explore the connections between targets/goals and other economic or industry sectors (such as energy or healthcare), mentions of construction and real estate activities were used to identify specific targets as candidates for direct or indirect dependence.

2. For sources that identify required, planned, or accomplished activities/actions to achieve specific targets or goals, descriptions that mention construction and real estate activities were used to identify specific targets as candidates for direct or indirect dependence.

3. For sources that analyze the interconnections and links between the agenda's targets, connection to the targets of Goal 11 (Make cities and human settlements inclusive, safe, resilient and sustainable) was used to identify specific targets as candidates for direct or indirect dependence. 


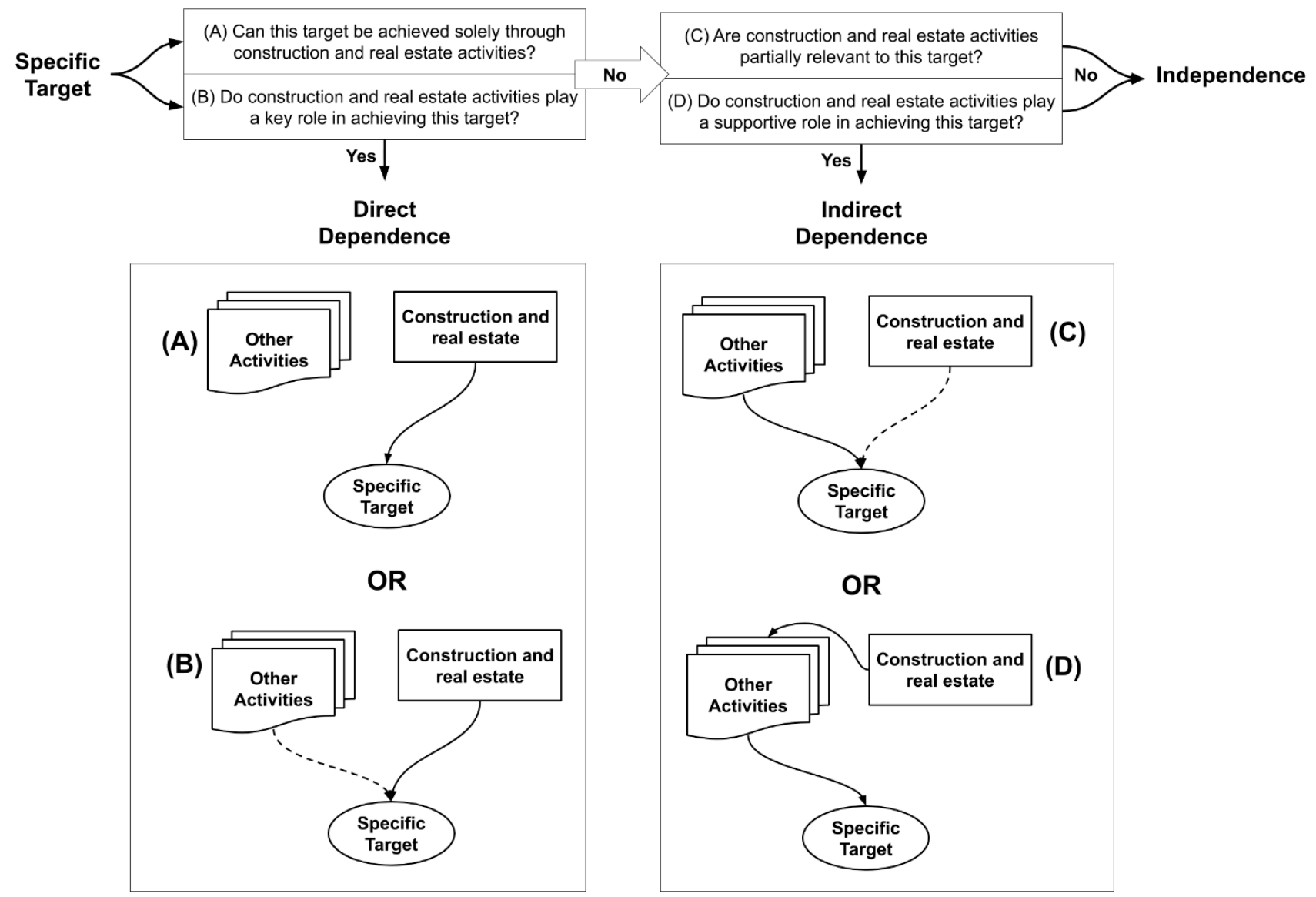

Figure 1. Process for defining direct and indirect dependence of SDG targets on the construction and real estate activities.

The targets identified were then analyzed based on their distribution across the 17 goals. Additionally, the targets were also analyzed using the categories proposed by The UN Sustainable Development Solutions Network (SDSN) and elaborated by Engberg-Pedersen and Zwart [36,41], namely:

1. Process Targets/Means of implementation (representing $48 \%$ of the agenda's targets).

2. Outcome Targets (representing $52 \%$ of the agenda's targets) that are focused on:

(a) people (representing $17 \%$ of the agenda's targets),

(b) society-wide (representing $22 \%$ of the agenda's targets), or

(c) the environment (representing 13\% of the agenda's targets).

The methodology and results of this research are then compared to other literature sources including sources that conduct an internal linkage map for the agenda's targets $[16,19]$. Finally, the implications of the study and future research directions are discussed in order to highlight possible synergies as well as the types of partnerships needed to further advance the agenda. Figure 2 summarizes the research methodology. 


\section{Literature Review}

Examining literature pertaining to the 2030 agenda as well construction and real estate activities

\section{Systematic Examination of SDG targets}

o Identifying targets with direct dependance on ○ Identifying targets with indirect dependance to construction and real estate activities construction and real estate activities

\section{Analyzing Targets}

○ Analyzing the potential of construction and real estate $\quad$ o Comparing results to other findings available in the to support achieving the agenda's targets literature

\section{Identifying implications and future directions}

Figure 2. Research methodology.

\section{BACKGROUND}

\section{Construction, Real Estate and Sustainability}

The sustainability of construction, real estate, infrastructure, and urban development have increasingly received the attention of governments, private organizations, and researchers alike. This is justified because of the risks and threats these activities pose to the natural environment as well as their effect on the social, economic, cultural and political dimensions of sustainability [12,42-45]. Today, $40 \%$ of the global energy consumption and more than $30 \%$ of the global carbon dioxide equivalent emissions are attributed to buildings-making the building sector the single most significant industry in terms of emissions [14,46-49]. In addition, the building sector consumes $12 \%$ of freshwater and $30 \%$ of raw material and it generates approximately $20 \%$ of water effluents and as much as $40 \%$ of landfill waste globally [46]. While there are variations in the estimated environmental consequences of construction, real estate, infrastructure, and urban development, there appears to be a broad census on the need for major transformations in the industry in order to embrace sustainability and to contribute to sustainable development.

Such transformations are considered necessary not only to avoid the projected $56 \%$ increase in its emissions by 2030 but also to sustain and support the urban, economic, social, scientific, and cultural changes projected in the near future. By 2050, it is expected that two-thirds of the global population will be living in urban areas [50]. The world's largest 750 cities, including the 14 new megacities that are expected to emerge, will require more than 500 million $\mathrm{m}^{2}$ of new office space and more than 250 million new homes [46,51]. The urbanization, which will be mainly 
occurring in emerging markets (such as Asia and Africa), will be coupled with an exponential growth in the construction and real estate industries: in the next 5 to 10 years, the global construction output is expected to reach 15 million US dollars (double its 2014 level) and the global construction industry value is expected to increase yearly by approximately $7 \%$ [51,52]. Two key trends are apparent in the current studies: (1) sustainability and technology will be key drivers for these sectors in the coming years, and (2) investment and developments in infrastructure will play a central role in the next 20 years.

While sustainability in construction, buildings and real estate has become common in developed countries, the share of "green projects" in developing counties is significantly lower [53]. A series of reports published by the World Economic Forum and the Boston Consulting Group explored the future of the construction industry [45,54]. They described some key trends that include (1) the global expansion of engineering and construction companies (i.e., carrying activities on a more global scale), (2) the massive financing required to close the global infrastructure gap, (3) the need to increase the resilience of buildings and infrastructure to disasters, and (4) the needed transformations in the politics and regulations concerning construction [45,54]. The reports point to immediate actions required on the company level, such as transformations in strategies, governance, processes and technology [45]. These company-level actions will also need to be complemented with sector-level transformations (such as coordinated communication, collaboration and interaction with civil society and the public sector) as well as government-level actions (such as changes in regulations and policies concerning building codes, promotion of technological adaptation, and transformations in the procurement processes to make them more transparent and life-cycle focused) [45]. Within the World Economic Forum's initiative named "Shaping the Future of Construction initiative", the transformations that construction and real estate need in the upcoming years is explored through future scenarios [54]. Digitalization, capturing new opportunities and enabling the organization emerged as the common imperatives in all the scenarios explored. One of the explored scenarios is the "green reboot" (also referred to in other references as "green goes mainstream" [55]), where environmentally friendly methods and sustainable materials are popularized due to the conflicts over resources and climate change [54]. In this scenario, the construction and real estate industries will experience a major shift that is driven by international and national regulations that will create new opportunities for research and development (on topics such as energy, water, materials, emissions and biodiversity) and innovative sustainable technologies [54].

While there is certainty in the growth of the construction and real estate sectors, current studies highlight that infrastructure will play a key role in realizing development $[33,51,52,56-58]$. The projections indicate that growth in the construction sector will revolve around infrastructure 
in both emerging markets (such as China and India) and developed markets (such as Europe and the US) [33,59]. Although in 2015 more than $\$ 9$ trillion (14\% of the global GDP) were invested in infrastructure globally, $\$ 4.7$ trillion additional yearly investments (in transport, water, energy and telecommunication) are required to keep up with the projected global GDP growth and to meet the UN sustainable development goals [56,58]. Most of this new investment will be in the Asia-Pacific region (which is expected to represent about $60 \%$ of global infrastructure spending by 2025), Latin America and the Middle East [56,58]. A report published by the Economist Intelligence Unit in 2019 highlights that infrastructure lies at the center of the UN 2030 Agenda because it requires building the right types of projects to reduce environmental impacts as well as to create the needed social, economic and cultural development $[33,60]$. Pocock et al. highlight that these developments require transformations in the design, construction, management and funding processes of projects to ensure that they are within the capacity of local communities and in line with the local culture [60].

To build sustainably requires moving beyond business as usual [33,61]. Researchers exploring the definition of sustainability in design and business have indicated that moving towards "true sustainability" requires expanding the focus beyond economic and short-term concerns [62,63]. In her exploration of sustainable innovation, Cucuzzella proposes a multistep framework where system-wide innovations are required to redirect unsustainable practices [63]. Vefago and Avellaneda identify some of those unsustainable practices in architecture [64]. In their exploration of the meaning of sustainability in business, Dyllick and Muff propose 4 levels: (1) business as usual, which is centred on economic concerns, (2) Sustainability 1.0, marked by a broadened business concern to include all the dimensions of sustainability while still focusing on creating economic value, (3) Sustainability 2.0, marked by a move beyond the economic value towards creating value across all the pillars of sustainability (i.e., social, environmental, economic and cultural), and finally (4) Sustainability 3.0, identified by an "outside-in approach" that is focused on the sustainability challenges (rather than economic concerns) and that aims at creating value for the common good [62]. These model echo the ideas proposed in seminal work such as that of Naess [65].

These models challenge the approach used by most of the environmental certification and rating systems that have governed the environmental activities of construction and real estate in past years. While the available environmental standards have resulted in some marginal improvements, their focus on incremental improvement, ecoefficiency and harm reduction are hindering progress towards transformational development [11,66]. Findings presented in recent market reports support the fact that the standards are becoming increasingly adopted due to their positive economic outcomes (i.e., creating shareholder value) rather than their environmental 
virtues [53,67]. In fact, the existing environmental standards in the industry could be considered as part of business as usual because they are focused on product-level improvements [63] and follow an inside-out approach [62]. Although some studies have presented possible links between popular environmental rating tools and the SDGs [25,26], they risk amplifying optimization approaches (i.e., optimizing credits pursued in order to maximize rating with the lowest possible cost or, in this case, nominal contribution to the SDGs) and the misuse of these systems (or specific credits that were assessed to contribute to the 2030 Agenda) as design guidelines [5]. Additionally, and for more than a decade, scholars have been highlighting the systemic failure embedded in standards, legal, and regulatory practices and have instead proposed market-driven and market-oriented measures in order to accelerate progress towards sustainability [68-70]. An example of the success of such market-oriented measures can be seen in the carbon-trading schemes widely adopted today $[71,72]$.

\section{The 2030 Agenda and Its Sustainable Development Goals}

The SDGs emerged as an outcome of the Rio 20+ United Nations Summit in 2012 [73]. As presented in The Future We Want. Our Common Vision [74], the summit concluded by recognizing the need to establish global development guidelines that simultaneously consider human needs, environmental sustainability, human rights and partnerships [75]. The Agenda 2030 and the SDGs, which were detailed in Transforming our world [8], were developed through an inclusive participatory process before being approved by the heads of 193 countries [73]. The 17 goals and their 169 targets are structured around 5 key themes-people, planet, prosperity, peace and partnerships—known as the five Ps [76]. Unlike their predecessors, the Millennium Development Goals (MDGs), the SDGs offer a more detailed and realistic outlook, and they are much more ambitious and comprehensive with respect to both human and natural systems needs [19,22,75,77]. The SDGs also contain better coverage and balance between the economic, social and environmental dimensions of sustainable development and provide an opportunity to trigger systemic change towards a sustainable future [15]. Since their adoption, it was anticipated that the SDGs will strongly influence politics, capital flows, and development priorities [76]. The agenda's targets mark a clear departure from previous development programs because they directly hold the international community, including businesses, non-governmental organizations, and research institutions responsible for the implementation of the goals $[75,78,79]$. It was also clear that achieving these goals would require the emergence of original partnership structures to build new collaborations among private, public and research communities [73,76]. Following the adoption of the agenda, there has been a significant number of publications that explore, analyze, and, in some cases, criticize the SDGs. 
In a paper published in 2017, Carant presents a feminist critique of the UN development agendas (both the MDGs and the SDGs) and highlights some contradictions within the targets of the agenda [80]. She concludes that "they [the development agendas] rely too exclusively on problemsolution frames that aim to temper oppositionists' paradigms” [80]. Some scholars, as seen in the review presented by [73], also indicate that the global nature of the agenda and its top-down development approach limit its local application and its use as a framework for industries and economic sectors. However, although scaling down the global focus of the 17 goals is a challenging task, recent publications highlight the important role economic sectors, industries and individual organizations can play in achieving the targets of the agenda and can provide a clear direction on how the agenda can be scaled down [29,38,39,81]. Although critiquing and pointing out the limitations of these global agendas is important [80], the evidence in the literature is pointing to real commitments to the SDGs in the public and private sectors $[23,25,37,78]$. The current commitment to the 2030 Agenda could mean that, in the future, the construction sector will be expected to address the targets proposed by the agenda in its activities and projects $[25,82]$-As an example specific to the construction industry, the adoption of sustainability principles on the national levels has enforced the adoption of certification standards in public projects [83-85].

Some of the published research aims at understanding the progress and the challenges related to the implementation of the agenda. In a review paper published in 2018, Allen, Metternicht and Wiedmann [15] explored more than 50 publications pertaining to the SDGs and conducted a systematic review of 25 sources. They divided the literature into two main categories: (1) guides and toolkits (8 sources), and (2) academic and research contributions (17 sources). They then explored how each of the sources approached the SDGs. By comparing the national implementation reports of 26 countries with the approaches they identified, the authors were able to isolate key gaps in the agenda's implementation progress and strategies. They found the national reports to be lacking policy evaluation, interlinkage assessment, prioritization, systems thinking, quantitative modelling, scenario building and needs assessment [15]. Other sources indicate that the submitted national reports mainly focused on assessing the alignment of the SDGs with existing plans and policies instead of developing policies and strategies that integrate the SDGs [22,73]. In another review paper, Gusmão Caiado et al. analyzed the operational issues in the SDGs by reviewing 55 recent articles on the topic [73]. They identified the differences in needs and experiences of individual urban areas as one of the biggest hurdles in achieving the SDG targets. They also established that information technology can provide key opportunities to tackle the topics of the SDGs [73]. Their conclusion in that regard is also supported by the findings of [35]. Finally, they used their review as a basis for proposing a new framework for achieving the SDGs that they based on 
continuous cycles of innovation, education and information, monitoring and implementation [73].

Another category of publications aims at investigating the possibilities, appropriate means and basic perquisites for achieving the SDGs. In a study published in 2019, Moyer and Bohl explore the possibility of achieving 8 of the human development-related SDG targets under different future scenarios: (1) current path, (2) consumption change, (3) decentralized solutions, (4) global technology, and (5) a combined approach [77]. By means of projections, they found that under the combined scenario (which they identified as the best case scenario) only $63 \%$ of the targets are achievable by 2030 [77]. They also found that the synergies and trade-offs between the goals require the targets to be prioritized differently in each of the proposed future scenarios [77]. Santika et al. investigated the additional energy demands required for achieving the SDGs [23]. From the 25 energy-related targets they identified, only three targets (namely target 3.8 sustainable agriculture, target 7.3 energy efficiency, and target 12.5 waste reduction) contributed to energy demand reduction. The other 22 targets require additional energy to be achieved (i.e., would result in additional energy demands) [23]. This highlights the need to consider energy infrastructure beyond SDG 7 as well as to develop energy scenarios that consider the overall increase in demand needed to achieve the agenda 2030 targets.

Finally, another group of publications aimed at prioritizing the goals based on local needs and understanding the research priorities of experts in different geographic regions. In a second publication by Allen et al., the authors use multi-criteria analysis (MCA) to prioritize the 43 targets using 57 indicators for 22 countries in the Arab Region [20]. They used three criteria for their MCA: (1) level of urgency, (2) systemic impact, and (3) policy gap [20]. They also conducted a network analysis for the targets, similar to that conducted by Le Blanc [19]. What is important to note is that in their MCA each of the 3 criteria resulted in a different set of priorities [20]. This highlights the complexity of the agenda's implementation and the conflicting priorities it presents. In their study, Salvia et al. explored the SDGs receiving the most attention from experts in different geographic locations [22]. They found a correlation between the SDGs studied with the challenges observed in the experts' geographic regions. They also found that some of the more challenging SDG topics (such as hunger, reducing inequalities, decent work, health, and partnerships) are receiving significantly less attention [22]. Their findings also highlight the complexity of the comprehensive implementation of the 2030 Agenda, and hint at the limitations of the topic-specific approach that is common in academic research. Their findings also stress the inevitable trade-offs embedded in the agenda-conclusions that correlate with the findings in other publications $[15,20,23,73]$. 


\section{Construction and the 2030 Agenda}

The five Ps proposed in the 2030 Agenda require different stakeholders (including governments, institutions, and businesses) to expand their scope of action beyond environmental attributes to all the interconnected dimensions of sustainable development [8]. Recent publications have attempted to identify the different SDGs and targets where the construction industry can specifically contribute. Lynch and Mosbah point to SDG 1 (target focused on reducing the exposure to climate-related events), SDG 9 (target focused on building infrastructure that is supportive of economic development and human well-being), and SDG 11 (target that emphasizes the role of cities in construction work in the built environment) [9]. In addition to those 3 SDGs, Goubran et al. also point to the role of buildings and the construction sector in achieving the renewable energy goals within SDG 7, in ensuring attainment of the sustainable consumption and production targets in SDG 12, and in attaining the climate adaptation target of SDG 13 [14]. Di Foggia specifically relates energy efficiency in buildings and construction to SDGs 11 and 13 [86]. However, much of the available research is mainly focused on available sustainability assessment tools, standards and certifications, or uses single or region-specific case studies. These approaches limit the applicability of the findings and their ability to trigger transformative change.

Since the early 2000s, scholars of the built environment have been pointing to the inadequacy of assessment standards in capturing sustainability in its full complexity, and to the fact that they distort the definition of sustainability [69,87-89]. Recent literature highlights that even the most comprehensive tools, such as Leadership in Energy and Environmental Design (LEED) [90], ignore some important dimensions of sustainable development [91]. The available literature that reviews the dominant assessment and certification systems, standards, and tools also highlights their specific focus on energy performance [6,91-93] and a limited number of environmental elements [6,91]. Aspects such as resilience to natural disasters, economic assessment, and social dimensions (such as education and awareness, inclusiveness, local employment and stakeholder relations) are usually not considered [92,94]. In a recent publication, a group of researchers aimed to correlate the relative importance of assessment indicators with the UN SDGs in Jordan [25]. They found that the credits or points criteria of the available rating systems focus on SDG 3, 6, 7, 8, 9, 11, 12, 13, and 15 (a total of 9 out of the 17 SDGs) [25]. However, the authors do not precisely reveal how these credits contribute to the goals and do not present a target-level analysis [25]. They conclude by highlighting the need to further integrate the SDGs in the assessment of buildings [25]. The World Green Building Council, the managing global body of LEED certification [90], has concluded that green buildings can directly contribute to SDG 3 (noting the improvements green buildings bring to health and wellbeing), SDG 7 (noting the growth in the 
renewable energy sector that could be achieved through green buildings), SDG 8 (noting the ability of green buildings to create new jobs and grow the economy), SDG 9 (highlighting the potential of green buildings in spurring innovation and building resilient infrastructures), SDG 11 (indicating the creation of sustainable communities through green building projects), SDG 12 (including minimizing waste in the construction and management of green buildings), SDG 13 (through the reduced emissions green buildings offer), SDG 15 (in green buildings' commitment to improving biodiversity, reducing water usage and protecting forests) and SDG 17 (noting the potential of green buildings for creating global partnerships) [95]. These categories intersect with other findings reported in the literature, such as $[14,25,26]$. Other more recent research aims at proposing means for integrating the SDGs into the building design process through an analysis and mapping framework [96].

The Sustainable Development Solutions Network (SDSN) proposed the SDG index as a way to track progress and advancement towards the agenda's implementation [17,97]. Scholars pointed to the limitations of the index, however. By comparing the SDG index and the 2030 agenda, DiazSarachaga et al. highlight that the index does not consider all the sustainability pillars and neglects $60 \%$ of the agenda's targets due to data unavailability [18]. Wackernagel et al. identified a correlation between higher resource dependence and many performance indicators in the SDG index [98]. By mapping countries based on their human development index (HDI) and ecological footprint, they found that countries with higher HDI rankings and bigger ecological footprints score the highest in the SDG index [98]. They concluded that the SDG index might not be an adequate measure of progress towards sustainability (defined based on decoupling ecological footprint and human development) and to produce transformative change [98]. The gaps identified in the sustainability assessment tools of the construction and real estate sectors emphasize their inadequacy as a measure for the construction sector's influence within the 2030 Agenda because they marginalize certain SDGs and targets. To the best knowledge of the researcher, there are no available publications that aim to specifically assess the potential contribution of the construction industry in attaining the different targets of the 2030 Agenda or to analyze the specific targets' dependence on construction and real estate activities.

\section{RESULTS}

Through the content analysis conducted, 74 of the 169 targets of the agenda (44\%) were found to be dependent on construction and real estate activities-of which 29 targets (17\%) are directly dependent and 45 targets (27\%) indirectly dependent. Table A1 in the Appendix presents the full list of targets identified, describes the reason for allocation and lists the relevant references for each selected target. When looking at the distribution of the targets across the goals (presented in Figure 3 and 
Table 1), it is clear that construction and real estate activities have a role to play, either directly or indirectly, in all 17 SDGs. SDG 11 was found to be the most dependent on construction and real estate activities: of the 10 listed targets, 8 were directly dependent and 1 was indirectly dependent. Also, more than $30 \%$ of the targets of SDGs 6,7 and 15 were directly dependent on construction and real estate activities. Finally, all the targets of SDG 7 were dependent on construction and real estate activities-2 targets directly and 3 indirectly.

Table 1. SDG targets are directly or indirectly dependent on construction and real estate activities.

\begin{tabular}{|c|c|c|c|c|}
\hline \multirow{2}{*}{ Sustainable Development Goal } & \multicolumn{3}{|c|}{ Dependence on construction and real estate activities } & \multirow{2}{*}{$\begin{array}{c}\text { Percent of total } \\
\text { targets } \\
\end{array}$} \\
\hline & Direct & Indirect & Prevailing dependence* & \\
\hline 7: Affordable and clean energy & 2 & 3 & Indirect & $100 \%$ \\
\hline 11: Sustainable cities and communities & 8 & 1 & Direct & $90 \%$ \\
\hline 6: Clean water and sanitation & 4 & 3 & Direct & $88 \%$ \\
\hline 9: Industry, innovation and infrastructure & 2 & 3 & Indirect & $63 \%$ \\
\hline 13: Climate action & 1 & 2 & Indirect & $60 \%$ \\
\hline 8: Decent work and economic growth & 0 & 7 & Indirect & $58 \%$ \\
\hline 12: Responsible consumption and production & 1 & 5 & Indirect & $55 \%$ \\
\hline 15: Life on land & 4 & 2 & Direct & $50 \%$ \\
\hline 2: Zero hunger & 1 & 3 & Indirect & $50 \%$ \\
\hline 14: Life below water & 2 & 2 & Direct & $40 \%$ \\
\hline 4: Quality education & 1 & 3 & Indirect & $40 \%$ \\
\hline 3: Good health and well-being & 2 & 2 & Indirect & $31 \%$ \\
\hline 1: No poverty & 1 & 1 & Direct & $29 \%$ \\
\hline 5: Gender equality & 0 & 2 & Indirect & $22 \%$ \\
\hline 17: Partnerships for the goals & 0 & 4 & Indirect & $21 \%$ \\
\hline 10: Reduced inequalities & 0 & 1 & Indirect & $10 \%$ \\
\hline 16: Peace, justice and strong institutions & 0 & 1 & Indirect & $8 \%$ \\
\hline
\end{tabular}

* Goals with equal numbers of targets with direct and indirect dependence are assumed to be directly dependent on construction and real estate activities.

(A)

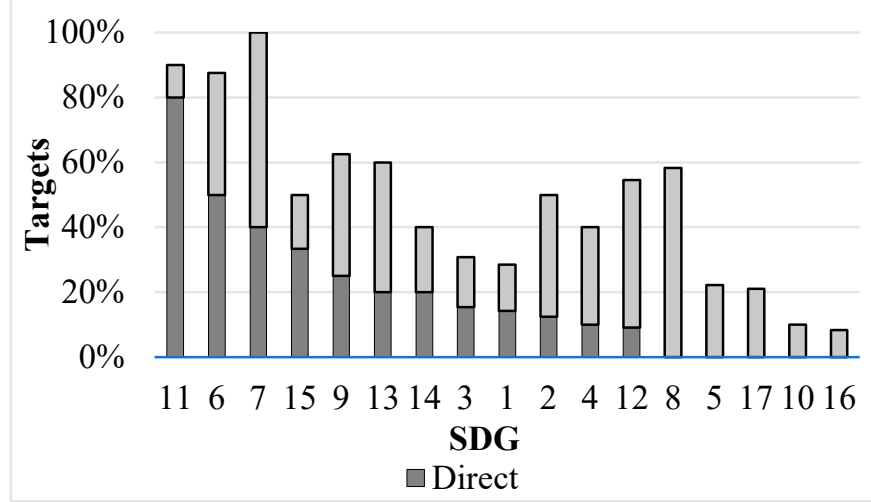

(B)

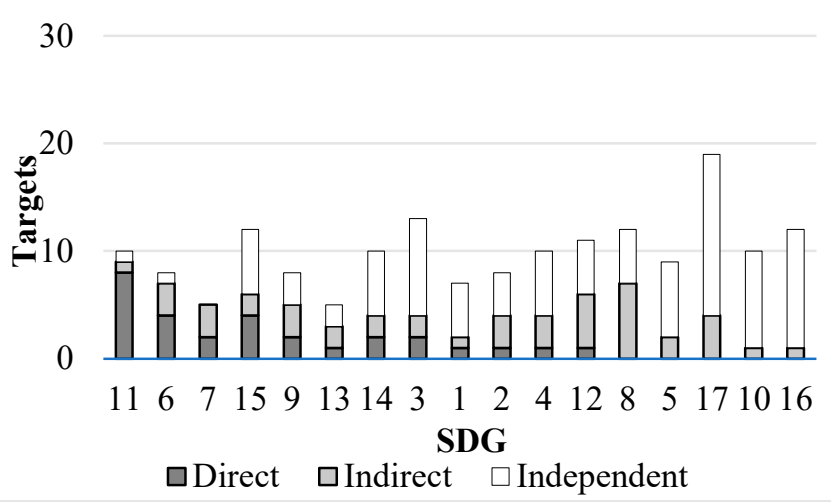

Figure 3. SDG-specific targets directly or indirectly dependent on construction and real estate activities presented (A) in percentage terms (organized by decreasing value of direct dependence) and (B) by aggregate number of targets (following the same order as $\mathbf{A}$ ). 
By using the categorization proposed by Engberg-Pedersen and Zwart [36], the analysis revealed that more than $80 \%$ of the environmentally centred outcome targets depend on construction and real estate activities: 11 of 22 ( $50 \%$ of the environmentally centred targets) directly and 8 ( $36 \%$ of the environmentally centred targets) indirectly. Additionally, more than $25 \%$ of the targets in each of the categories were dependent on construction and real estate activities (Figure 4). Figure 5 presents the dependence in detail-using a diagram format designed by [40] and the categories proposed by [36,41]. Figure 6 presents an illustrative map of the SDGs' dependence on construction and real estate activities where the SDGs are: (1) organized across 4 quadrants (society, people, environment and means) based on the prevailing category of construction and real estate dependent targets, (2) sized relative to their overall dependence on construction and real estate activities (the bigger the icon the larger the dependence of the goal on construction and real estate activities), and (3) placed relative to the center of the map based on the proportion of direct or indirect dependence (the closer to the center the SDGs are, the more direct the connection). Since the analysis was conducted at the target level, it is important to note that Figure 6 aims at simplifying the findings of the research to only focus on goals by using simple visual elements and identifying prevailing trends observed for each of the 17 SDGs. For the most accurate depiction of the results please refer to Figure 5.

(A)

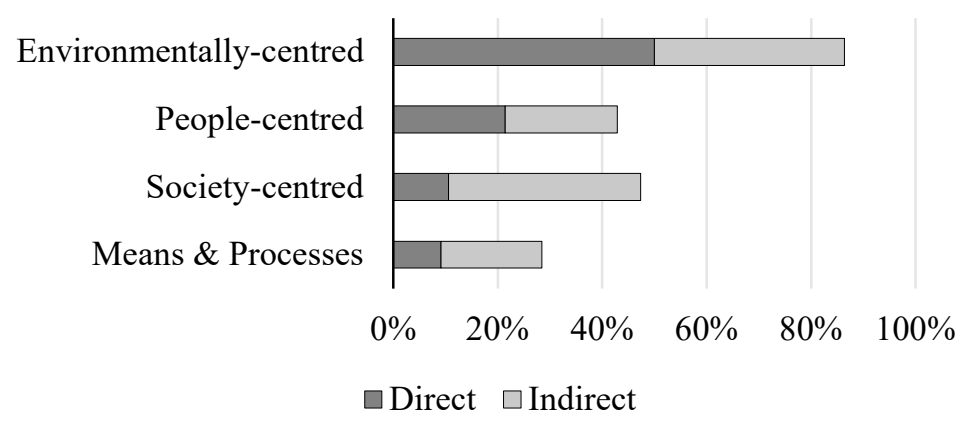

(B)

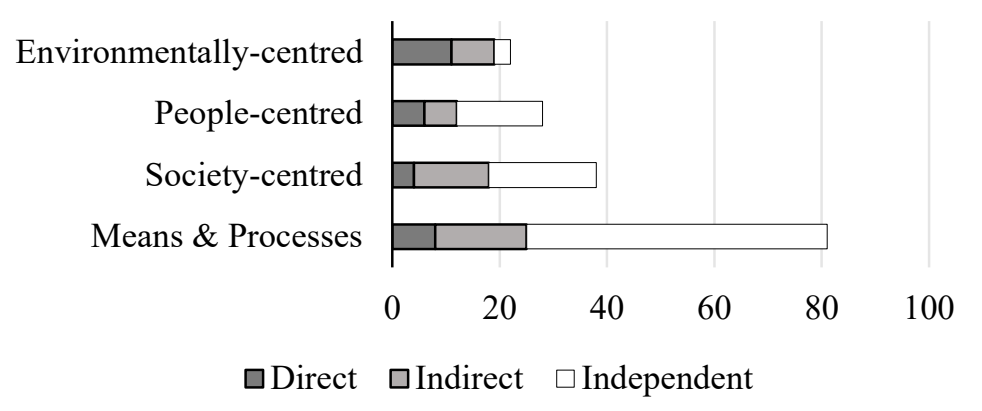

Figure 4. Targets directly and indirectly dependent on construction and real estate activities categorized according to Engberg-Pedersen [36,41], presented (A) in percentage terms (organized by decreasing value of direct dependence) and (B) by aggregate number of targets. 


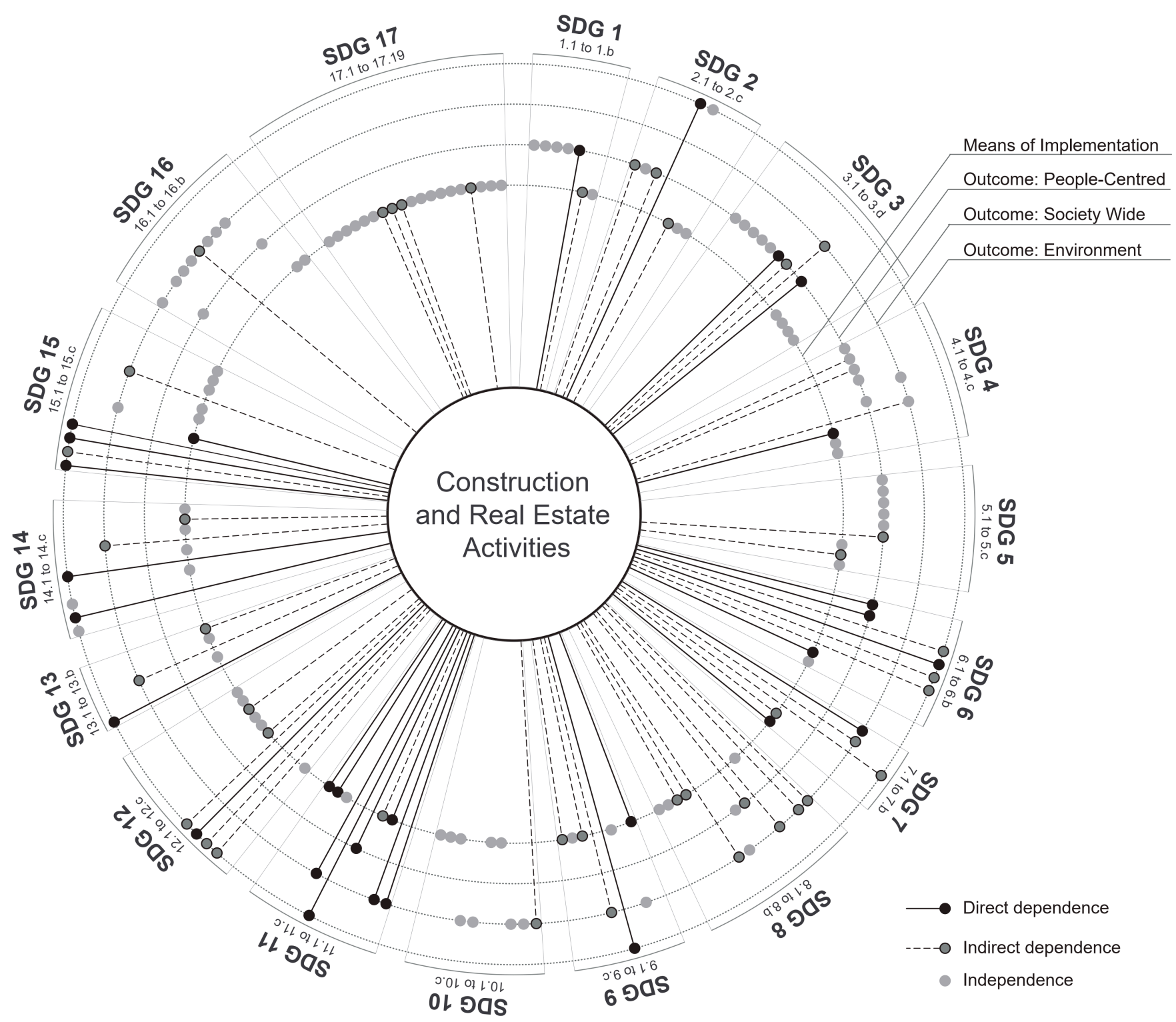

Figure 5. A visual map of the dependency of SDGs on construction and real estate activities. Targets are ordered clockwise and distributed across the 4 categories proposed by Engberg-Pedersen and Zwart [36,41]. The chart format is based on the work of Maes et al. [40]. 


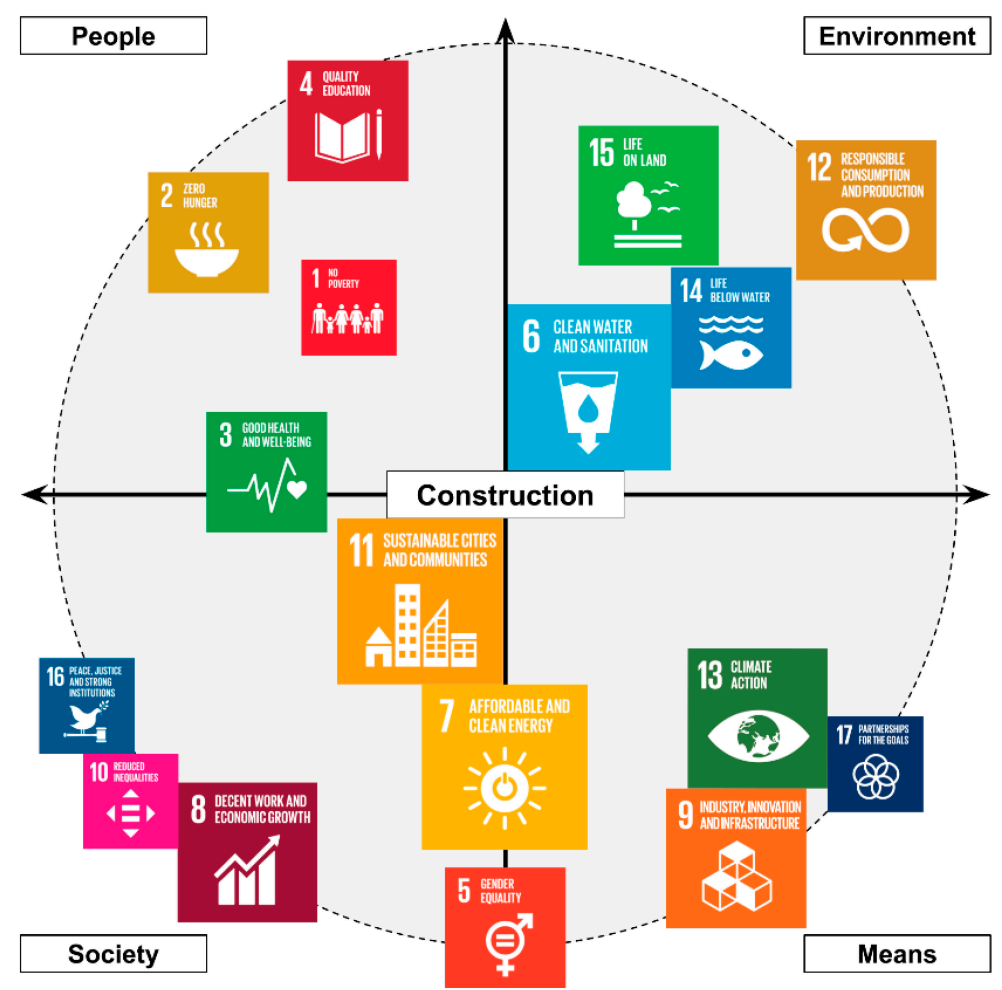

Figure 6. Illustrative map of SDGs' dependence on construction and real estate activities. The size of each SDG icon is relative to its dependence on construction and real estate activities (larger icons indicate larger overall dependence as seen in Table 1), the location in the quadrant correlates with the prevailing type of the construction/real-estate-dependent targets (categories proposed by Engberg-Pedersen [36,41]), and the distance from the center relates to the nature of the link between the targets and construction work (the closer to the center the SDGs are the more direct the connection). For the most accurate depiction of the results please refer to Figure 5.

\section{DISCUSSION}

By comparing the results of this research with other findings in the literature, it is clear that the available sources do not offer a comprehensive overview of the dependence of the 2030 Agenda on construction and real estate activities. Le Blanc presents a linkage map for all the SDG targets where the targets are connected based on their synergies or similarity [19], and concluded that the targets of SDG 11, which is generally cited as the most relevant to construction and real estate [14], are connected to SDG 3 through 5 targets, SDG 1 through 4 targets, SDG 12 and SDG 10 through 3 targets each, SDG 6 through 2 targets, and SDG 16 through only 1 target. The analysis conducted in this research revealed that the two SDGs (namely SDG 1 and SDG 3) (which Le Blanc [19] found to be most connected to SDG 11) are not the most highly dependent on construction and real estate activities: SDG 1 has only 1 target (14\% of the goal's targets) directly dependent on construction and real estate activities, and SDG 3 has 2 targets directly (15\% of the goal's targets) and 2 indirectly (15\% of the goal's targets) dependent on construction and real estate activities. The research on building projects, such as that of Alawneh 
et al. [25,26], proposed links between sustainable non-residential buildings in Jordan and SDGs 3, 6, 7, 8, 9, 11, 12, 13 and 15. In their 2018 publication [26], a questionnaire was completed by 55 experts from academia and professional practice to develop a formula to calculate the contribution (what they called a contribution index) of water and energy credits of the LEED v2.2 to the SDGs. The statistical analysis revealed a strong relationship between the LEED credits selected and the SDGs selected. However, the relation was only explored on the goal level and there is no data provided to indicate the specific targets the LEED credits are tackling. Additionally, Alawneh et al. did not clarify the filtering process used to arrive at the specific goals tested (9 of the 17). In their 2019 paper [25], they extended this analysis to other major environmental rating tools and used the Delphi method to further validate their findings. However, the analysis also remained focused on the goal level-with no specific targets mentioned. The World Green Building Council also proposes that green buildings can contribute to SDGs 15 and 17 [95]. However, no clear methodology was presented on how this selection was made and no specific targets were mentioned. Goubran et al. [14] used reports published by the UN (and its affiliate association) and the IPCC to propose links between SDG 7, 11, 12 and 13 and sustainable real estate on targetand, when possible, indicator-levels. However, their focus was mainly on commercial real estate activities and the sources for their study were limited to a small number of reports. Unlike these recent publications, the research presented in this article uses a clear methodological process to analyze the agenda at the target level. It also uses available sources to support the selection of relevant targets. The process used in this research is utilized in academic sources that analyze the links between the SDGs, energy [16,23], health [24] and urban ecosystems [40]. Additionally, this research does not limit the possible sustainable-developed-focused construction and real estate activities to those prescribed by LEED or other rating tools.

Table 2 compares the findings of the sources reviewed with the results of this research. It is important to note that links between construction and real estate on the one hand and SDGs 11 and 12, on the other hand, are common to all the findings. This study also suggests the direct dependence of SDG 14 (life below water) on construction and real estate activities. Unlike previously published studies, this research also suggests the indirect dependence of SDG 2 (no hunger), SDG 4 (quality education), and SDG 5 (reduced inequalities-5.6, Ensure universal access to sexual and reproductive health and reproductive rights as agreed in accordance with the Programme of Action of the International Conference on Population and Development and the Beijing Platform for Action and the outcome documents of their review conferences; 5.b, Enhance the use of enabling technology, in particular information and communications technology, to promote the empowerment of women) on construction and real estate activities. This indirect dependence is based on the need for building or 
revitalizing infrastructure and facilities for education, health care, water, energy, and information technology [16,23,24,35]. The results of this research highlight two important insights: (1) that the role of the construction and real estate sectors in the agenda cannot be limited to or defined based on SDG 11, and (2) that analyzing the internal links between the agenda's targets (i.e., an internal analysis of the agenda) is limiting since it does not present the intersections and dependencies of the economic sectors and their activities.

Table 2. Comparison between links proposed between building construction and real estate and the SDGs.

\begin{tabular}{|c|c|c|c|c|c|c|c|c|c|c|c|c|c|c|c|c|c|}
\hline \multirow{2}{*}{ Available References } & \multicolumn{17}{|c|}{ SDGs } \\
\hline & 1 & 2 & 3 & 4 & 5 & 6 & 7 & 8 & 9 & 10 & 11 & 12 & 13 & 14 & 15 & 16 & 17 \\
\hline $\begin{array}{l}\text { Le Blanc (2015) [19] } \\
\text { Based on the agenda's internal links to SDG } 11\end{array}$ & 口 & & व & & & o & & & & 0 & 0 & 0 & & & & 0 & \\
\hline $\begin{array}{l}\text { Czerwinska (2018)_-World Green Building } \\
\text { Council [95] } \\
\text { Focused on green buildings in general (with specific } \\
\text { references to LEED) }\end{array}$ & & & व & & & & 0 & व & 口 & & 0 & 0 & ם & & 0 & & व \\
\hline $\begin{array}{l}\text { Alawneh } \text { et al. }(\mathbf{2 0 1 8 , 2 0 1 9 )}[25,26] \\
\text { Focused on non-residential buildings in Jordan and } \\
\text { rating tools (especially LEED) }\end{array}$ & & & व & & & 口 & 0 & व & व & & 0 & 0 & ㅁ & & 0 & & \\
\hline $\begin{array}{l}\text { Goubran et al. (2019) [14] } \\
\text { Focused on targets related to sustainable real estate }\end{array}$ & & & & & & & 0 & & & & 0 & 0 & 0 & & & & \\
\hline $\begin{array}{l}\text { This research } \\
\text { Direct dependence }\end{array}$ & 口 & & 口 & & & 口 & & & & & 0 & & & 0 & 0 & & \\
\hline Indirect dependence & & o & & ם & o & & 0 & 0 & o & o & & o & o & & & 0 & a \\
\hline
\end{tabular}

Other publications that were focused on the energy sector $[23,32,86]$ highlight that the role of the energy sector goes significantly beyond the scope of SDG 7 (Energy). Le Blanc only proposes connections between SDG 7 and SDG 1, 10 and 12 [19]. However, Santika et al. determine quantifiable connections between energy, in terms of energy demand, with 13 SDGs; only excluding SDG 10 (reduced equalities), 14 (life below water), 15 (life on land) and 16 (peace, justice and strong institutions) [23]. Additionally, McCollum et al. suggest, based on a review of available literature, that the energy focused SDG 7 can be linked to targets across all of the agenda's goals except SDG 17 (partnership) [32]. These findings indicate that confining the scope of the analysis to the specific topics covered by the targets of the SDGs (i.e., topics mentioned directly in the targets of the agenda) without considering their broader economic context could lead to overlooking the role of economic or industry sectors. Jones et al. identified 102 SDG targets touching all 17 goals and calling for action in urban ecosystems, which included targets that require building physical infrastructures [40]. Although their research was mainly focused on natural environments in urban areas, their analysis hints to the broad relationship between construction and the SDGs. Additionally, the links 
they propose between urban ecosystems and the SDGs move beyond the linkage other scholars proposed between SDG 15 (life on land) and SDG 11 (sustainable cities and communities) [19,20,73]. This further supports the fact that a specific topic-such as ecosystems, buildings, or infrastructure-can not be contained within one or a few of the SDGs. Instead, it infiltrates the targets of most goals. Similar to the energy sector and urban ecosystems, the results of this research highlighted the strong dependence of the agenda on construction and real estate activities. It also emphasizes the failure of goal-specific approaches and the need for interdisciplinary research to achieve the agenda's objectives [22].

It is important to highlight that, in the available literature, there is a limited number of studies that specifically explore how current construction, real estate, infrastructure, and urban development practices (i.e., business as usual) hinder progress toward SDGs. However, researchers have highlighted that trade-offs are common and that focusing only on specific goals or targets could result in negative impacts on other goals and targets [20,40,77]. As an example, by focusing on increasing the renewable energy share in buildings (helping to achieve targets in SDG 7 as suggested by [26]) without considering targets in SDG 8 could result in distorted economic growth and could reinforce the coupling between growth and environmental degradation if renewable energy infrastructure is not developed sustainability. Doing so without considered the targets in SDG 11 could result in deterioration in the urban cultural heritage if renewable systems are added to buildings or the built environment without considering their historic or urban value. Doing so without considering the targets in SDG 12 and SDG 13 could lead to further environmental deterioration if unsustainable consumption and production patterns are used in the manufacturing of renewable energy systems. Another example that has been presented in the literature includes trade-offs between access to affordable housing (SDG 11) and terrestrial ecosystems protection (SDG 15) [40] or trade-offs between ending hunger (SDG 2) and terrestrial or water ecosystems (SDGs 14 and 15) [77].

The adoption of and demand for sustainability principles and practices has been steadily increasing in the construction and real estate sectors. This makes them well-positioned to lead the implementation of the agenda [14,46,53]. By specifying the direct and indirect dependence of specific SDG targets on construction and real estate activities, the findings presented in this article could help stakeholders to explore new partnership opportunities. Additionally, governmental and non-governmental organizations working toward SDGs that are indirectly dependent on these sectors (such as SDG 5, 8, 10, 16, or others presented in Figure 1A) should explore multi-stakeholder collaborations within their projects in order to fully utilize available synergies, including non-governmental organizations partnering with private firms, start-ups, academic institutions, or innovation labs. These synergies are critical to achieving multiple targets across different SDGs simultaneously. An example of such synergies could be seen in the case study presented by [96]. 
As an illustrative example, a school in an economically disadvantaged location could aim to serve people with disabilities as well as women and girls (contributing to SDG 4), could use an integrated design process (contributing to SDG 11), could integrate renewable energy sources into the design (contributing to SDG 7), and could ensure the local sourcing of materials and human resources (contributing to SDG 8). The building could include computer and information technology amenities with access to the internet (contributing to SDG 5 and 9), could integrate community food production facilities into the building program (contributing to SDG 2), and could include waste management capabilities (contributing to SDG 12). The building could also be constructed to provide shelter from flooding and other natural disasters (contributing to SDG 1 and 13), as well as clean water sources to the local community (contributing to SDG 6). The facility could even be used as a didactic/teaching tool for climate change education [99,100] (contributing to SDG 13 and further contributing to SDG 4). Given that the construction of such a building would require new partnerships to be developed-between governmental, non-governmental and private organizations-the facility will also be contributing to SDG 17. This exemplary school would be contributing directly to targets that span 13 of the SDGs. These contributions would be mediated by construction (i.e., the process of constructing the school), thus demonstrating the centrality and relevance of construction and real estate to the agenda. However, such multi-functional projects are only possible when these synergies are explored in the early design phases of construction projects. To the best of our knowledge, frameworks and processes for such deep integration are not readily available in the literature.

\section{CONCLUSIONS}

The construction and real estate sectors are one of the main contributors to the global economy and global employment market [31]. Until recently, these industries have been mainly focused on the environmental dimension of sustainable development [5-7]. Since the adoption of the 2030 Agenda, the construction and real estate sectors have struggled to adapt to the expanded definition it presents [9-12], and remain focused on the environmental issues [5,6]. In recent years, the available literature on the 2030 Agenda and its SDGs have exponentially increased. However, less focus has been placed on exploring the potential role of the different economic sectors in supporting the realization of the SDGs and their targets. Previous research on the link between construction and the 2030 Agenda either (A) focused on specific sub-sectors (such as buildings) rather than the whole industry when analyzing links to the 2030 Agenda [25,95], or (B) analyzed the internal linkages within the targets in the agenda-using SDG 11 as the focus of construction activities-without reference to specific industry sectors [16-20]. These approaches inadequately presented the overall links between the SDG targets and the construction and real estate sectors. 
The research presented in this article used a multi-step research methodology to analyze the dependence of the 2030 Agenda's targets on construction and real estate activities. Using more than 60 recent publications on the topic, this article presents a review of literature that explores the relationship of construction (and its sub-sectors) to the 2030 Agenda as well as sources that analyze the links between the agenda's targets. This research uses direct content analysis to identify SDG targets [8] that are directly or indirectly dependent on construction and real estate activities. This article illustrates the potential contribution of construction and real estate activities using a comprehensive definition for these sectors. The results of the analysis reveal that $44 \%$ of the agenda's targets spanning all 17 SDGs are dependent on construction and real estate activities. Specifically, 6 of the 17 SDGs were found to have a prevailing direct dependence, and 12 of the 17 SDGs were found to have at least one target directly dependent on construction and real estate activities. The findings underscore that over $80 \%$ of the targets of SDG 11 (sustainable cities and communities), SDG 6 (clean water and sanitation), and SDG 7 (affordable and clean energy) depend on construction and real estate activities. Additionally, $86 \%$ of the environmentally focused outcome targets (19 of the 22) were found to be dependent on construction and real estate activities.

This research contributes to the literature on the implementation of the 2030 agenda. This article specifically identified how the building, construction and real estate sectors interact with the SDGs-a key component of the SDG sector road map proposed by the World Business Council for Sustainable Development (WBCSD) [29]. This article provides academics as well as public and private organizations with a comprehensive overview of the potential role construction and real estate can play in achieving specific targets both directly and indirectly. The research provides meaningful insights to organizations and businesses that can help to trigger new partnerships and to maximize the contribution of construction projects to the 2030 Agenda. Research focused on sustainability in the built environment needs to develop and test adequate frameworks that facilitate the integration of the SDGs and their targets into construction and real estate practices. More research in the fields of design, management and policy is needed to explore and to analyze the processes and methods that could be used to reach such integration.

\section{CONFLICTS OF INTEREST}

The author declares that there is no conflict of interest.

\section{ACKNOWLEDGMENTS}

The author would like to acknowledge the support received by SSHRC through the Vanier Canada Graduate Scholarship as well as the support received through Concordia University and the Individualized Program. 


\section{APPENDIX}

Table A1. List of SDG targets with direct or indirect links to the construction industry—using target categories proposed by Engberg-Pedersen [36,41].

\begin{tabular}{|c|c|c|c|c|c|c|c|c|}
\hline \multirow{2}{*}{ SDGs Target } & \multirow{2}{*}{$\begin{array}{l}\text { Process } \\
\text { Targets }\end{array}$} & \multicolumn{3}{|c|}{ Outcome Targets } & \multicolumn{2}{|c|}{$\begin{array}{c}\text { Dependence on } \\
\text { construction }\end{array}$} & \multirow{2}{*}{ Reason for allocation } & \multirow{2}{*}{ References } \\
\hline & & $\begin{array}{l}\text { People- } \\
\text { centred }\end{array}$ & $\begin{array}{c}\text { Society- } \\
\text { wide }\end{array}$ & $\begin{array}{c}\text { Environ- } \\
\text { ment }\end{array}$ & Direct & Indirect & & \\
\hline
\end{tabular}

\section{Goal 1. End poverty in all its forms everywhere}

By 2030, build the resilience of the poor and those in vulnerable situations and reduce their

1.5 exposure and vulnerability to climate-related extreme events and other economic, social and environmental shocks and disasters
Achieving this target requires upgrading and constructing new infrastructures to reduce and mitigate exposure to climate-related disasters (including access to renewable energy) and access to affordable and resilient shelter. Also, adapt the designs to the local needs and context.

Ensure significant mobilization of resources from a variety of sources, including through enhanced development cooperation, in order to provide

1.a adequate and predictable means for developing countries, in particular least developed countries, to implement programmes and policies to end poverty in all its dimensions
"Architecture cannot lift people out of poverty, but the built environment can affect the impact of poverty on people's lives through access to housing and institutions that are affordable." [39]

Goal 2. End hunger, achieve food security and improved nutrition and promote sustainable agriculture

By 2030, end hunger and ensure access by all

2.1 people, in particular the poor and people in vulnerable situations, including infants, to safe, nutritious and sufficient food all year round
Achieving this target requires improving and updating the infrastructure (facilities and transport and energy infrastructures) related to food production-including production, packaging, and distribution facilities. Also ensuring selecting buildings materials that reduce stress on agricultural land. 
Table A1. Cont.

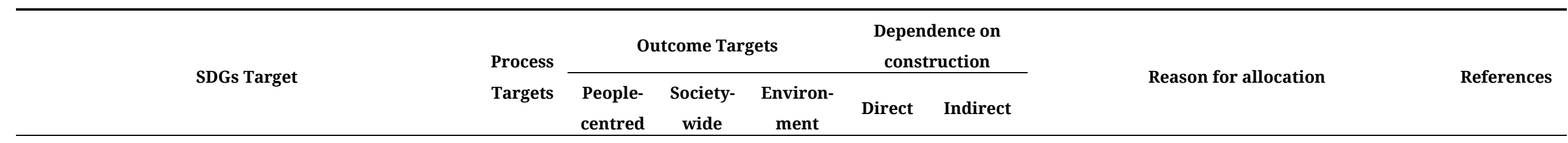

By 2030, double the agricultural productivity and

incomes of small-scale food producers, in

particular women, indigenous peoples, family

farmers, pastoralists and fishers, including

through secure and equal access to land, other productive resources and inputs, knowledge,

financial services, markets and opportunities for

Achieving this target requires improving the

access to land and ensuring equal access to basic

infrastructures (energy, financing, and training).

Also, practicing responsible real estate investment

strategies when dealing with agricultural land.

value addition and non-farm employment

By 2030, ensure sustainable food production

systems and implement resilient agricultural

practices that increase productivity and

2.4 production, that help maintain ecosystems, that

strengthen capacity for adaptation to climate

change, extreme weather, drought, flooding and

other disasters and that progressively improve

Achieving this target requires improvements and

developments in the infrastructure networks

(water, energy, and communication) as well as

building new facilities (for storage, packaging and

land and soil quality

distribution) that will directly support achieving

this target.

Increase investment, including through enhanced

international cooperation, in rural infrastructure,

agricultural research and extension services,

2.a technology development and plant and livestock

gene banks in order to enhance agricultural

productive capacity in developing countries, in

productive capacity in developing
particular least developed countries 
Table A1. Cont.

\begin{tabular}{|c|c|c|c|c|c|c|c|c|}
\hline \multirow{2}{*}{ SDGs Target } & \multirow{2}{*}{$\begin{array}{l}\text { Process } \\
\text { Targets }\end{array}$} & \multicolumn{3}{|c|}{ Outcome Targets } & \multicolumn{2}{|c|}{$\begin{array}{c}\text { Dependence on } \\
\text { construction }\end{array}$} & \multirow{2}{*}{ Reason for allocation } & \multirow{2}{*}{ References } \\
\hline & & $\begin{array}{l}\text { People- } \\
\text { centred }\end{array}$ & $\begin{array}{l}\text { Society- } \\
\text { wide }\end{array}$ & $\begin{array}{l}\text { Environ- } \\
\text { ment }\end{array}$ & Direct & Indirect & & \\
\hline
\end{tabular}

Goal 3. Ensure healthy lives and promote well-being for all at all ages

By 2020, halve the number of global deaths and

injuries from road traffic accidents

By 2030, ensure universal access to sexual and

reproductive health-care services, including for

3.7 family planning, information and education, and the integration of reproductive health into national strategies and programmes

Achieve universal health coverage, including financial risk protection, access to quality

3.8 essential health-care services and access to safe, effective, quality and affordable essential medicines and vaccines for all

By 2030, substantially reduce the number of
Achieving this target requires building new

transport infrastructure and upgrading the

current infrastructure to minimize risks induced

by poor design and construction.

Achieving this target requires expanding the

current health infrastructure (or building new

व facilities) to give required access to services and

education, as well as ensuring access to modern forms of energy and ICT.

Achieving this target requires developing and upgrading the health infrastructure (facilities, equipment) especially in remote and underserved areas. This requires information technology and energy infrastructure development. This might also require new real estate incentives to ensure that services are provided where they are most needed.

Achieving this target requires the building sector to minimize or to eliminate its contribution to air, water and soil contamination. The building sector is responsible for a large portion of the world's pollution [14]. Efforts have to be made within this sector to curb its pollution. 
Table A1. Cont.

\begin{tabular}{|c|c|c|c|c|c|c|c|c|c|}
\hline & \multirow{2}{*}{ SDGs Target } & \multirow{2}{*}{$\begin{array}{l}\text { Process } \\
\text { Targets }\end{array}$} & \multicolumn{3}{|c|}{ Outcome Targets } & \multicolumn{2}{|c|}{$\begin{array}{c}\text { Dependence on } \\
\text { construction }\end{array}$} & \multirow{2}{*}{ Reason for allocation } & \multirow{2}{*}{ References } \\
\hline & & & $\begin{array}{l}\text { People- } \\
\text { centred }\end{array}$ & $\begin{array}{c}\text { Society- } \\
\text { wide }\end{array}$ & $\begin{array}{c}\text { Environ- } \\
\text { ment }\end{array}$ & Direct & Indirect & & \\
\hline \multicolumn{10}{|c|}{ Goal 4. Ensure inclusive and equitable quality education and promote lifelong learning opportunities for all } \\
\hline 4.2 & $\begin{array}{l}\text { By } 2030 \text {, ensure that all girls and boys have access to } \\
\text { quality early childhood development, care and pre- } \\
\text { primary education so that they are ready for } \\
\text { primary education }\end{array}$ & & व & & & & 口 & $\begin{array}{l}\text { Achieving this target requires providing new } \\
\text { facilities (or upgrading existing facilities) to } \\
\text { provide access to pre-primary care and education } \\
\text { (such as on-site daycare). }\end{array}$ & [38] \\
\hline 4.3 & $\begin{array}{l}\text { By } 2030 \text {, ensure equal access for all women and men } \\
\text { to affordable and quality technical, vocational and } \\
\text { tertiary education, including university }\end{array}$ & & a & & & & 口 & $\begin{array}{l}\text { Achieving this target requires developing the } \\
\text { infrastructure for creating safe spaces for training } \\
\text { and education. This could also require expanding } \\
\text { energy and ICT infrastructure. }\end{array}$ & [32] \\
\hline 4.7 & $\begin{array}{l}\text { By 2030, ensure that all learners acquire the } \\
\text { knowledge and skills needed to promote sustainable } \\
\text { development, including, among others, through } \\
\text { education for sustainable development and } \\
\text { sustainable lifestyles, human rights, gender } \\
\text { equality, promotion of a culture of peace and non- } \\
\text { violence, global citizenship and appreciation of } \\
\text { cultural diversity and of culture's contribution to } \\
\text { sustainable development }\end{array}$ & & & 口 & & & 口 & $\begin{array}{l}\text { "Furthermore, the built environment can provide } \\
\text { training opportunities regarding the sustainable } \\
\text { performance of buildings, settlements and urban } \\
\text { areas for both users and craftsmen. In } \\
\text { development, as well as in use, buildings and } \\
\text { communal facilities can interact with and promote } \\
\text { a sustainable culture of usage." [39] }\end{array}$ & {$[39,40]$} \\
\hline 4.a & $\begin{array}{l}\text { Build and upgrade education facilities that are child, } \\
\text { disability and gender sensitive and provide safe, } \\
\text { non-violent, inclusive and effective learning } \\
\text { environments for all }\end{array}$ & 口 & & & & 口 & & $\begin{array}{l}\text { Achieving this target requires building and } \\
\text { upgrading educational facilities and services } \\
\text { within them (including energy, water, and ICT). }\end{array}$ & [34] \\
\hline
\end{tabular}


Table A1. Cont.

\begin{tabular}{|c|c|c|c|c|c|c|c|c|c|}
\hline & \multirow{2}{*}{ SDGs Target } & \multirow{2}{*}{$\begin{array}{l}\text { Process } \\
\text { Targets }\end{array}$} & \multicolumn{3}{|c|}{ Outcome Targets } & \multicolumn{2}{|c|}{$\begin{array}{l}\text { Dependence on } \\
\text { construction }\end{array}$} & \multirow{2}{*}{ Reason for allocation } & \multirow{2}{*}{ References } \\
\hline & & & $\begin{array}{l}\text { People- } \\
\text { centred }\end{array}$ & $\begin{array}{l}\text { Society- } \\
\text { wide }\end{array}$ & $\begin{array}{c}\text { Environ- } \\
\text { ment }\end{array}$ & Direct & Indirect & & \\
\hline \multicolumn{10}{|c|}{ Goal 5. Achieve gender equality and empower all women and girls } \\
\hline 5.6 & $\begin{array}{l}\text { Ensure universal access to sexual and reproductive } \\
\text { health and reproductive rights as agreed in } \\
\text { accordance with the Programme of Action of the } \\
\text { International Conference on Population and } \\
\text { Development and the Beijing Platform for Action and } \\
\text { the outcome documents of their review conferences }\end{array}$ & & & 口 & & & 0 & $\begin{array}{l}\text { Like target } 3.7 \text { with a focus on providing } \\
\text { facilities (clinics, hospitals or information } \\
\text { centers). }\end{array}$ & {$[32,39]$} \\
\hline 5.b & $\begin{array}{l}\text { Enhance the use of enabling technology, in particular } \\
\text { information and communications technology, to } \\
\text { promote the empowerment of women }\end{array}$ & 0 & & & & & 口 & $\begin{array}{l}\text { Achieving this target requires upgrading and } \\
\text { developing ICT networks and energy } \\
\text { infrastructure. }\end{array}$ & {$[23,39]$} \\
\hline \multicolumn{10}{|c|}{ Goal 6. Ensure availability and sustainable management of water and sanitation for all } \\
\hline 6.1 & $\begin{array}{l}\text { By 2030, achieve universal and equitable access to } \\
\text { safe and affordable drinking water for all }\end{array}$ & & 口 & & & 0 & & $\begin{array}{l}\text { Achieving this target requires developing } \\
\text { drinking water infrastructure-including } \\
\text { developing the drinking water network, } \\
\text { filtration plants, desalination plants and } \\
\text { other facilities (including energy } \\
\text { infrastructure). }\end{array}$ & {$[23,32,40]$} \\
\hline 6.2 & $\begin{array}{l}\text { By 2030, achieve access to adequate and equitable } \\
\text { sanitation and hygiene for all and end open } \\
\text { defecation, paying special attention to the needs of } \\
\text { women and girls and those in vulnerable situations }\end{array}$ & & 口 & & & 0 & & $\begin{array}{l}\text { Achieving this target requires developing } \\
\text { drinking sanitation infrastructure-including } \\
\text { developing and increasing the capacity of } \\
\text { sewage treatment plants. It also requires the } \\
\text { construction of sanitation facilities on the } \\
\text { local level. }\end{array}$ & {$[37,38,40]$} \\
\hline
\end{tabular}


Table A1. Cont.

\begin{tabular}{|c|c|c|c|c|c|c|c|c|c|}
\hline & \multirow{2}{*}{ SDGs Target } & \multirow{2}{*}{$\begin{array}{l}\text { Process } \\
\text { Targets }\end{array}$} & \multicolumn{3}{|c|}{ Outcome Targets } & \multicolumn{2}{|c|}{$\begin{array}{c}\text { Dependence on } \\
\text { construction }\end{array}$} & \multirow{2}{*}{ Reason for allocation } & \multirow{2}{*}{ References } \\
\hline & & & $\begin{array}{l}\text { People- } \\
\text { centred }\end{array}$ & $\begin{array}{c}\text { Society- } \\
\text { wide }\end{array}$ & $\begin{array}{c}\text { Environ- } \\
\text { ment }\end{array}$ & Direct & Indirect & & \\
\hline 6.3 & $\begin{array}{l}\text { By 2030, improve water quality by reducing } \\
\text { pollution, eliminating dumping and minimizing } \\
\text { release of hazardous chemicals and materials, } \\
\text { halving the proportion of untreated wastewater and } \\
\text { substantially increasing recycling and safe reuse } \\
\text { globally }\end{array}$ & & & & 口 & & 口 & $\begin{array}{l}\text { Buildings and construction have a large role } \\
\text { in the contamination of groundwater: } \\
\text { "Building materials that do not contribute to } \\
\text { groundwater contamination should be chosen, } \\
\text { whether during extraction, construction or in } \\
\text { use." [39] }\end{array}$ & {$[26,39,40]$} \\
\hline 6.4 & $\begin{array}{l}\text { By 2030, substantially increase water-use efficiency } \\
\text { across all sectors and ensure sustainable withdrawals } \\
\text { and supply of freshwater to address water scarcity } \\
\text { and substantially reduce the number of people } \\
\text { suffering from water scarcity }\end{array}$ & & & & 0 & 0 & & $\begin{array}{l}\text { In the US, } 88 \% \text { of freshwater consumption is } \\
\text { attributed to the commercial real estate } \\
\text { sector [101]. Efficiency gaols in the real estate } \\
\text { sector-as well as in the construction sector- } \\
\text { can play a key role in reducing overall } \\
\text { consumption. These reductions can directly } \\
\text { help ensure the sustainability of withdrawals. }\end{array}$ & {$[14,26,40]$} \\
\hline 6.5 & $\begin{array}{l}\text { By 2030, implement integrated water resources } \\
\text { management at all levels, including through } \\
\text { transboundary cooperation as appropriate }\end{array}$ & & & & 口 & & 口 & $\begin{array}{l}\text { Achieving this target requires improvements } \\
\text { and developments in infrastructure (energy, } \\
\text { communication, and water technologies) to } \\
\text { reinforce the targets. Additionally, it requires } \\
\text { establishing and sharing circular and } \\
\text { wastewater management best practices in } \\
\text { these sectors. }\end{array}$ & {$[32,38,40]$} \\
\hline
\end{tabular}


Table A1. Cont.

\begin{tabular}{|c|c|c|c|c|c|c|c|c|c|}
\hline & \multirow{2}{*}{ SDGs Target } & \multirow{2}{*}{$\begin{array}{l}\text { Process } \\
\text { Targets }\end{array}$} & \multicolumn{3}{|c|}{ Outcome Targets } & \multicolumn{2}{|c|}{$\begin{array}{l}\text { Dependence on } \\
\text { construction }\end{array}$} & \multirow{2}{*}{ Reason for allocation } & \multirow{2}{*}{ References } \\
\hline & & & $\begin{array}{l}\text { People- } \\
\text { centred }\end{array}$ & $\begin{array}{l}\text { Society- } \\
\text { wide }\end{array}$ & $\begin{array}{c}\text { Environ- } \\
\text { ment }\end{array}$ & Direct & Indirect & & \\
\hline 6.6 & $\begin{array}{l}\text { By } 2020 \text {, protect and restore water-related } \\
\text { ecosystems, including mountains, forests, wetlands, } \\
\text { rivers, aquifers and lakes }\end{array}$ & & & & 口 & & 口 & $\begin{array}{l}\text { Improvements in construction and real estate } \\
\text { practices around water will lead to lowering } \\
\text { the pollution affecting water ecosystems. } \\
\text { Additionally, protecting and restoring these } \\
\text { ecosystems will require improvements and } \\
\text { developments in energy and water } \\
\text { infrastructure. Finally, these sectors' material } \\
\text { consumption also plays a role in the } \\
\text { degradation and pollution of the ecosystems } \\
\text { mentioned in the target. }\end{array}$ & {$[32,39,40]$} \\
\hline 6.a & $\begin{array}{l}\text { By 2030, expand international cooperation and } \\
\text { capacity-building support to developing countries in } \\
\text { water- and sanitation-related activities and } \\
\text { programmes, including water harvesting, } \\
\text { desalination, water efficiency, wastewater treatment, } \\
\text { recycling and reuse technologies }\end{array}$ & 口 & & & & 0 & & $\begin{array}{l}\text { Capacity building requires constructing water } \\
\text { harvesting and desalination facilities, as well } \\
\text { as wastewater treatment, recycling and reuse } \\
\text { facilities. }\end{array}$ & {$[26,34,40]$} \\
\hline \multicolumn{10}{|c|}{ Goal 7. Ensure access to affordable, reliable, sustainable and modern energy for all } \\
\hline 7.1 & $\begin{array}{l}\text { By } 2030 \text {, ensure universal access to affordable, } \\
\text { reliable and modern energy services }\end{array}$ & & & 口 & & 口 & & $\begin{array}{l}\text { Achieving this target requires expanding the } \\
\text { energy infrastructure. It also requires } \\
\text { increasing the use of renewables in the } \\
\text { energy sector-which requires building new } \\
\text { facilities and developing new projects (land) } \\
\text { for the production of renewable energy. }\end{array}$ & $\begin{array}{c}{[23,25,32,38,} \\
40]\end{array}$ \\
\hline
\end{tabular}


Table A1. Cont.

\begin{tabular}{|c|c|c|c|c|c|c|c|c|c|}
\hline & \multirow{2}{*}{ SDGs Target } & \multirow{2}{*}{$\begin{array}{l}\text { Process } \\
\text { Targets }\end{array}$} & \multicolumn{3}{|c|}{ Outcome Targets } & \multicolumn{2}{|c|}{$\begin{array}{c}\text { Dependence on } \\
\text { construction }\end{array}$} & \multirow{2}{*}{ Reason for allocation } & \multirow{2}{*}{ References } \\
\hline & & & $\begin{array}{l}\text { People- } \\
\text { centred }\end{array}$ & $\begin{array}{l}\text { Society } \\
\text {-wide }\end{array}$ & $\begin{array}{c}\text { Environ- } \\
\text { ment }\end{array}$ & Direct & Indirect & & \\
\hline 7.2 & $\begin{array}{l}\text { By 2030, increase substantially the share of } \\
\text { renewable energy in the global energy mix }\end{array}$ & & & ø & & & ฮ & $\begin{array}{l}\text { Achieving this target requires expanding the } \\
\text { use of renewables in the construction and real } \\
\text { estate sectors. It also requires expanding } \\
\text { renewable energy infrastructure and networks. }\end{array}$ & $\begin{array}{c}{[14,23,25,26,} \\
38,40]\end{array}$ \\
\hline 7.3 & $\begin{array}{l}\text { By 2030, double the global rate of improvement in } \\
\text { energy efficiency }\end{array}$ & & & & ๑ & & 口 & $\begin{array}{l}\text { Buildings are one of the biggest consumers of } \\
\text { electricity on the global level [14,102]. Energy } \\
\text { efficiency in buildings has a significant role in } \\
\text { increasing overall energy efficiency. This } \\
\text { requires improvements in design strategies } \\
\text { (including use of passive strategies) and use of } \\
\text { energy-efficient equipment. }\end{array}$ & $\begin{array}{c}{[14,25,26,38,} \\
39]\end{array}$ \\
\hline 7.a & $\begin{array}{l}\text { By 2030, enhance international cooperation to } \\
\text { facilitate access to clean energy research and } \\
\text { technology, including renewable energy, energy } \\
\text { efficiency and advanced and cleaner fossil-fuel } \\
\text { technology, and promote investment in energy } \\
\text { infrastructure and clean energy technology }\end{array}$ & व & & & & & घ & $\begin{array}{l}\text { The real estate sector plays a key role (along } \\
\text { with other economic sectors) in achieving this } \\
\text { target. It requires investing and adhering to } \\
\text { best practices as well as sharing know-how } \\
\text { related to energy. It also requires improving } \\
\text { energy infrastructure. }\end{array}$ & {$[34,37]$} \\
\hline 7.b & $\begin{array}{l}\text { By 2030, expand infrastructure and upgrade } \\
\text { technology for supplying modern and sustainable } \\
\text { energy services for all in developing countries, in } \\
\text { particular least developed countries, small island } \\
\text { developing States and landlocked developing } \\
\text { countries, in accordance with their respective } \\
\text { programmes of support }\end{array}$ & ø & & & & घ & & $\begin{array}{l}\text { It requires expanding and developing energy } \\
\text { infrastructure. }\end{array}$ & [40] \\
\hline
\end{tabular}


Table A1. Cont.

\begin{tabular}{|c|c|c|c|c|c|c|c|c|}
\hline \multirow{2}{*}{ SDGs Target } & \multirow{2}{*}{$\begin{array}{l}\text { Process } \\
\text { Targets }\end{array}$} & \multicolumn{3}{|c|}{ Outcome Targets } & \multicolumn{2}{|c|}{$\begin{array}{c}\text { Dependence on } \\
\text { construction }\end{array}$} & \multirow{2}{*}{ Reason for allocation } & \multirow{2}{*}{ References } \\
\hline & & $\begin{array}{l}\text { People- } \\
\text { centred }\end{array}$ & $\begin{array}{l}\text { Society- } \\
\text { wide }\end{array}$ & $\begin{array}{c}\text { Environ- } \\
\text { ment }\end{array}$ & Direct & Indirect & & \\
\hline
\end{tabular}

Goal 8. Promote sustained, inclusive and sustainable economic growth, full and productive employment and decent work for all

Sustain per capita economic growth in accordance

8.1

with national circumstances and, in particular, at

least 7 percent gross domestic product growth per

annum in the least developed countries

Achieve higher levels of economic productivity

through diversification, technological upgrading and

innovation, including through a focus on high-value

added and labour-intensive sectors

Improve progressively, through 2030, global resource

efficiency in consumption and production and

endeavour to decouple economic growth from

8.4 environmental degradation, in accordance with the

10-Year Framework of Programmes on Sustainable

Consumption and Production, with developed

countries taking the lead
The construction and real estate sectors play

a key role in GDP growth considering their

contribution to the economy. Additionally,

sustainable construction and real estate can

help to create new growth opportunities.

The construction sector is one of the most

labour-intensive. Improvements in this sector

can help achieve this target [45,54]. This

requires upgrading the supporting industry

and supply chain for construction and real

estate to make use of automation and energy

and communication technologies.

The construction and building sectors

significantly contribute to environmental

degradation. Achieving this target requires

improvements and progress within the

$[25,26,34$,

construction and real estate sectors. The 
Table A1. Cont.

\begin{tabular}{|c|c|c|c|c|c|c|c|c|c|}
\hline & \multirow{2}{*}{ SDGs Target } & \multirow{2}{*}{$\begin{array}{l}\text { Process } \\
\text { Targets }\end{array}$} & \multicolumn{3}{|c|}{ Outcome Targets } & \multicolumn{2}{|c|}{$\begin{array}{c}\text { Dependence on } \\
\text { construction }\end{array}$} & \multirow{2}{*}{ Reason for allocation } & \multirow{2}{*}{ References } \\
\hline & & & $\begin{array}{l}\text { People- } \\
\text { centred }\end{array}$ & $\begin{array}{c}\text { Society- } \\
\text { wide }\end{array}$ & $\begin{array}{c}\text { Environ- } \\
\text { ment }\end{array}$ & Direct & Indirect & & \\
\hline 8.5 & $\begin{array}{l}\text { By 2030, achieve full and productive } \\
\text { employment and decent work for all } \\
\text { women and men, including for } \\
\text { young people and persons with } \\
\text { disabilities, and equal pay for work } \\
\text { of equal value }\end{array}$ & & व & & & & व & \multirow{2}{*}{$\begin{array}{l}\text { Working conditions and safety in the construction sector- } \\
\text { including that of migrant construction workers-have been } \\
\text { put in the spotlight a number of times in recent years. The } \\
\text { industry—along with other labour-intensive industries (such } \\
\text { as mining and forestry) [103]—plays an important role in } \\
\text { leading and setting a trend for change. }\end{array}$} & \multirow{2}{*}{$\begin{array}{c}{[19,26,34,39,} \\
104]\end{array}$} \\
\hline 8.8 & $\begin{array}{l}\text { Protect labour rights and promote } \\
\text { safe and secure working } \\
\text { environments for all workers, } \\
\text { including migrant workers, in } \\
\text { particular women migrants, and } \\
\text { those in precarious employment }\end{array}$ & & & व & & & व & & \\
\hline 8.9 & $\begin{array}{l}\text { By } 2030 \text {, devise and implement } \\
\text { policies to promote sustainable } \\
\text { tourism that creates jobs and } \\
\text { promotes local culture and products }\end{array}$ & 口 & & & & & व & $\begin{array}{l}\text { Architecture, design and real estate (tourist developments, } \\
\text { land-use planning, mapping of cultural sites) play a key role } \\
\text { in the promotion of local heritage, culture and products } \\
\text { [105]. These sectors should focus on development in those } \\
\text { directions and could support this target. }\end{array}$ & [37] \\
\hline 8.10 & $\begin{array}{l}\text { Strengthen the capacity of domestic } \\
\text { financial institutions to encourage } \\
\text { and expand access to banking, } \\
\text { insurance and financial services for } \\
\text { all }\end{array}$ & 0 & & & & & 口 & $\begin{array}{l}\text { Achieving this target requires building new facilities (bank } \\
\text { branches) to provide modern banking services, to upgrade } \\
\text { existing facilities, or expanding banking service points } \\
\text { (requiring real estate activities), as well as investment in and } \\
\text { development of information and communication } \\
\text { infrastructure. These construction activities are key to } \\
\text { addressing the indicator related to this target: (a) Number of } \\
\text { commercial bank branches per 100,000 adults and (b) number } \\
\text { of automated teller machines (ATMs) per 100,000 adults. }\end{array}$ & {$[32,34]$} \\
\hline
\end{tabular}


Table A1. Cont.

\begin{tabular}{|c|c|c|c|c|c|c|c|c|}
\hline \multirow{2}{*}{ SDGs Target } & \multirow{2}{*}{$\begin{array}{l}\text { Process } \\
\text { Targets }\end{array}$} & \multicolumn{3}{|c|}{ Outcome Targets } & \multicolumn{2}{|c|}{$\begin{array}{l}\text { Dependence on } \\
\text { construction }\end{array}$} & \multirow{2}{*}{ Reason for allocation } & \multirow{2}{*}{ Reference } \\
\hline & & $\begin{array}{l}\text { People- } \\
\text { centred }\end{array}$ & $\begin{array}{l}\text { Society- } \\
\text { wide }\end{array}$ & $\begin{array}{c}\text { Environ- } \\
\text { ment }\end{array}$ & Direct & Indirect & & \\
\hline
\end{tabular}

\section{Goal 9. Build resilient infrastructure, promote inclusive and sustainable industrialization and foster} innovation

Develop quality, reliable, sustainable and resilient infrastructure, including regional and transborder

9.1 infrastructure, to support economic development and human well-being, with a focus on affordable and equitable access for all

By 2030, upgrade infrastructure and retrofit

industries to make them sustainable, with increased resource-use efficiency and greater adoption of clean

9.4 and environmentally sound technologies and industrial processes, with all countries taking action in accordance with their respective capabilities

Enhance scientific research, upgrade the technological capabilities of industrial sectors in all countries, in particular developing countries,

9.5 including, by 2030, encouraging innovation and substantially increasing the number of research and development workers per 1 million people and public and private research and development spending
Achieving this target requires building and upgrading infrastructure (especially

$[23,25,26,32$, transport and energy)
Achieving this target requires upgrading infrastructure (especially energy and logistics).

Achieving this target requires documenting and disseminating innovations and developments in the construction and real estate sectors. "This requires training and the development of new competences at all levels in the building industry, as well as research and prototypes to test the potential of new tools, processes and solutions.” [39] It also requires the development of research facilities and information technology infrastructure. 
Table A1. Cont.

\begin{tabular}{|c|c|c|c|c|c|c|c|c|c|}
\hline & \multirow{2}{*}{ SDGs Target } & \multirow{2}{*}{$\begin{array}{l}\text { Process } \\
\text { Targets }\end{array}$} & \multicolumn{3}{|c|}{ Outcome Targets } & \multicolumn{2}{|c|}{$\begin{array}{c}\text { Dependence on } \\
\text { construction }\end{array}$} & \multirow{2}{*}{ Reason for allocation } & \multirow{2}{*}{ References } \\
\hline & & & $\begin{array}{l}\text { People- } \\
\text { centred }\end{array}$ & $\begin{array}{c}\text { Society- } \\
\text { wide }\end{array}$ & $\begin{array}{c}\text { Environ- } \\
\text { ment }\end{array}$ & Direct & Indirect & & \\
\hline $9 . \mathrm{a}$ & $\begin{array}{l}\text { Facilitate sustainable and resilient infrastructure } \\
\text { development in developing countries through } \\
\text { enhanced financial, technological and technical } \\
\text { support to African countries, least developed } \\
\text { countries, landlocked developing countries and small } \\
\text { island developing States }\end{array}$ & 口 & & & & & 口 & $\begin{array}{l}\text { Like target 9.5-with a focus on technical and } \\
\text { technological knowledge sharing and } \\
\text { collaboration. }\end{array}$ & {$[39,40]$} \\
\hline 9.c & $\begin{array}{l}\text { Significantly increase access to information and } \\
\text { communications technology and strive to provide } \\
\text { universal and affordable access to the Internet in } \\
\text { least developed countries by } 2020\end{array}$ & 口 & & & & & 口 & $\begin{array}{l}\text { Achieving this target requires development in } \\
\text { information and communication } \\
\text { infrastructure (such as the internet and } \\
\text { telecommunication). }\end{array}$ & {$[34,35]$} \\
\hline \multicolumn{10}{|c|}{ Goal 10. Reduce inequality within and among countries } \\
\hline 10.1 & $\begin{array}{l}\text { By } 2030 \text {, progressively achieve and sustain income } \\
\text { growth of the bottom } 40 \text { per cent of the population at } \\
\text { a rate higher than the national average }\end{array}$ & & & 口 & & & 口 & $\begin{array}{l}\text { Achieving this target requires improvement } \\
\text { in the procurement (local materials and } \\
\text { workers) and human resources practices in } \\
\text { the construction and real estate sectors-with } \\
\text { focus on small and medium enterprises [38] } \\
\text { and minorities [39]. Additionally, efficiency } \\
\text { gains can help to free up resources that could } \\
\text { be guided toward other development } \\
\text { targets [32]. }\end{array}$ & {$[32,38,39]$} \\
\hline
\end{tabular}


Table A1. Cont.

\begin{tabular}{|c|c|c|c|c|c|c|c|c|}
\hline \multirow{2}{*}{ SDGs Target } & \multirow{2}{*}{$\begin{array}{l}\text { Process } \\
\text { Targets }\end{array}$} & \multicolumn{3}{|c|}{ Outcome Targets } & \multicolumn{2}{|c|}{$\begin{array}{c}\text { Dependence on } \\
\text { construction }\end{array}$} & \multirow{2}{*}{ Reason for allocation } & \multirow{2}{*}{ References } \\
\hline & & $\begin{array}{l}\text { People- } \\
\text { centred }\end{array}$ & $\begin{array}{l}\text { Society- } \\
\text { wide }\end{array}$ & $\begin{array}{c}\text { Environ- } \\
\text { ment }\end{array}$ & Direct & Indirect & & \\
\hline
\end{tabular}

Goal 11. Make cities and human settlements inclusive, safe, resilient and sustainable

By 2030, ensure access for all to adequate, safe and

11.1 affordable housing and basic services and upgrade slums

By 2030, provide access to safe, affordable, accessible and sustainable transport systems for all, improving road safety, notably by expanding public transport,

11.2

with special attention to the needs of those in

vulnerable situations, women, children, persons with

disabilities and older persons

By 2030, enhance inclusive and sustainable

11.3

urbanization and capacity for participatory,

integrated and sustainable human settlement

planning and management in all countries
Achieving this target falls directly under the

activities of the real estate sector, both

private and public. It also requires the

development of sites, urban infrastructure

$[14,32,34,39$,

and building construction. It also entails

upgrading and developing existing urban spaces and infrastructure.

Achieving this target requires developing and improving existing transport systems as well as building new ones. It also requires developments in energy and communications infrastructure.

The construction and real estate sectors play

a key role in establishing best practices.

Achieving this target requires these sectors to promote and to adhere to sustainable construction practices. Additionally, the real 
Table A1. Cont.

\begin{tabular}{|c|c|c|c|c|c|c|c|c|c|}
\hline & \multirow{2}{*}{ SDGs Target } & \multirow{2}{*}{$\begin{array}{l}\text { Process } \\
\text { Targets }\end{array}$} & \multicolumn{3}{|c|}{ Outcome Targets } & \multicolumn{2}{|c|}{$\begin{array}{l}\text { Dependence on } \\
\text { construction }\end{array}$} & \multirow{2}{*}{ Reason for allocation } & \multirow{2}{*}{ References } \\
\hline & & & $\begin{array}{l}\text { People- } \\
\text { centred }\end{array}$ & $\begin{array}{l}\text { Society- } \\
\text { wide }\end{array}$ & $\begin{array}{c}\text { Environ- } \\
\text { ment }\end{array}$ & Direct & Indirect & & \\
\hline 11.4 & $\begin{array}{l}\text { Strengthen efforts to protect and safeguard the } \\
\text { world's cultural and natural heritage }\end{array}$ & 口 & & & & & o & $\begin{array}{l}\text { To achieve this target, the construction and } \\
\text { real estate sectors have to consider, promote } \\
\text { and integrate cultural (historic or human) } \\
\text { and natural heritage in their processes. } \\
\text { Architecture also plays a key role in } \\
\text { promoting and protecting local urban } \\
\text { heritage. }\end{array}$ & $\begin{array}{l}{[25,37,38,} \\
\quad 40]\end{array}$ \\
\hline 11.5 & $\begin{array}{l}\text { By 2030, significantly reduce the number of deaths } \\
\text { and the number of people affected and substantially } \\
\text { decrease the direct economic losses relative to global } \\
\text { gross domestic product caused by disasters, including } \\
\text { water-related disasters, with a focus on protecting the } \\
\text { poor and people in vulnerable situations }\end{array}$ & & 口 & & & 口 & & $\begin{array}{l}\text { Achieving this target requires the } \\
\text { construction and real estate sectors to } \\
\text { consider and to integrate resilience and } \\
\text { disaster planning in their processes. The } \\
\text { target also requires improving existing } \\
\text { infrastructure and buildings as well as } \\
\text { constructing new facilities and disaster } \\
\text { infrastructure. }\end{array}$ & {$[32,38-40]$} \\
\hline 11.6 & $\begin{array}{l}\text { By } 2030 \text {, reduce the adverse per capita } \\
\text { environmental impact of cities, including by paying } \\
\text { special attention to air quality and municipal and } \\
\text { other waste management }\end{array}$ & & & & 0 & 口 & & $\begin{array}{l}\text { The construction sector is one of the biggest } \\
\text { global polluters of air, water and soil [45,54]. } \\
\text { Additionally, construction and demolition } \\
\text { waste constitute one of the largest waste } \\
\text { streams. This sector's reductions in waste and } \\
\text { pollution will play a direct role in achieving } \\
\text { this target. }\end{array}$ & $\begin{array}{c}{[19,23,34,37,} \\
40]\end{array}$ \\
\hline
\end{tabular}


Table A1. Cont.

\begin{tabular}{|c|c|c|c|c|c|c|c|c|c|}
\hline & \multirow{2}{*}{ SDGs Target } & \multirow{2}{*}{$\begin{array}{l}\text { Process } \\
\text { Targets }\end{array}$} & \multicolumn{3}{|c|}{ Outcome Targets } & \multicolumn{2}{|c|}{$\begin{array}{c}\text { Dependence on } \\
\text { construction }\end{array}$} & \multirow{2}{*}{ Reason for allocation } & \multirow{2}{*}{ References } \\
\hline & & & $\begin{array}{l}\text { People- } \\
\text { centred }\end{array}$ & $\begin{array}{l}\text { Society- } \\
\text { wide }\end{array}$ & $\begin{array}{c}\text { Environ- } \\
\text { ment }\end{array}$ & Direct & Indirect & & \\
\hline 11.7 & $\begin{array}{l}\text { By 2030, provide universal access to safe, inclusive } \\
\text { and accessible, green and public spaces, in particular } \\
\text { for women and children, older persons and persons } \\
\text { with disabilities }\end{array}$ & & & ם & & 0 & & $\begin{array}{l}\text { Achieving this target requires designing, } \\
\text { constructing, and maintaining new open or } \\
\text { green public spaces or upgrading existing } \\
\text { ones. }\end{array}$ & $\begin{array}{l}{[25,34,39,} \\
\quad 40]\end{array}$ \\
\hline 11.b & $\begin{array}{l}\text { By 2020, substantially increase the number of cities } \\
\text { and human settlements adopting and implementing } \\
\text { integrated policies and plans towards inclusion, } \\
\text { resource efficiency, mitigation and adaptation to } \\
\text { climate change, resilience to disasters, and develop } \\
\text { and implement, in line with the Sendai Framework } \\
\text { for Disaster Risk Reduction 2015-2030, holistic } \\
\text { disaster risk management at all levels }\end{array}$ & 口 & & & & ø & & $\begin{array}{l}\text { New facilities and updates in existing } \\
\text { structures and infrastructure to achieve this } \\
\text { target. }\end{array}$ & {$[39,40]$} \\
\hline 11.c & $\begin{array}{l}\text { Support least developed countries, including through } \\
\text { financial and technical assistance, in building } \\
\text { sustainable and resilient buildings utilizing local } \\
\text { materials }\end{array}$ & 口 & & & & ø & & $\begin{array}{l}\text { The construction and real estate sectors, } \\
\text { especially in developed countries, have a key } \\
\text { role in supplying the know-how (best } \\
\text { practice) regarding the use of local material } \\
\text { and improving the built environment's } \\
\text { resilience. }\end{array}$ & [14] \\
\hline \multicolumn{10}{|c|}{ Goal 12. Ensure sustainable consumption and production patterns } \\
\hline 12.2 & $\begin{array}{l}\text { By 2030, achieve the sustainable management and } \\
\text { efficient use of natural resources }\end{array}$ & & & & 口 & & 0 & $\begin{array}{l}\text { The building industry is one of the largest } \\
\text { consumers of natural resources. The efforts } \\
\text { in resource management and efficient use in } \\
\text { this sector will have an important impact on } \\
\text { achieving this target. }\end{array}$ & $\begin{array}{c}{[23,25,26,32,} \\
37-39]\end{array}$ \\
\hline
\end{tabular}


Table A1. Cont.

\begin{tabular}{|c|c|c|c|c|c|c|c|c|c|}
\hline & \multirow{2}{*}{ SDGs Target } & \multirow{2}{*}{$\begin{array}{l}\text { Process } \\
\text { Targets }\end{array}$} & \multicolumn{3}{|c|}{ Outcome Targets } & \multicolumn{2}{|c|}{$\begin{array}{c}\text { Dependence on } \\
\text { construction }\end{array}$} & \multirow{2}{*}{ Reason for allocation } & \multirow{2}{*}{ References } \\
\hline & & & $\begin{array}{l}\text { People- } \\
\text { centred }\end{array}$ & $\begin{array}{l}\text { Society- } \\
\text { wide }\end{array}$ & $\begin{array}{c}\text { Environ- } \\
\text { ment }\end{array}$ & Direct & Indirect & & \\
\hline 12.3 & $\begin{array}{l}\text { By } 2030 \text {, halve per capita global food waste at the } \\
\text { retail and consumer levels and reduce food losses } \\
\text { along production and supply chains, including post- } \\
\text { harvest losses }\end{array}$ & & & & 0 & & व & $\begin{array}{l}\text { Achieving this target requires developing and } \\
\text { upgrading food production and storage } \\
\text { facilities as well as upgrades in retail spaces. } \\
\text { It also requires upgrades in energy and } \\
\text { transport infrastructure. }\end{array}$ & {$[23,32,38]$} \\
\hline 12.3 & $\begin{array}{l}\text { By } 2030 \text {, halve per capita global food waste at the } \\
\text { retail and consumer levels and reduce food losses } \\
\text { along production and supply chains, including post- } \\
\text { harvest losses }\end{array}$ & & & & 口 & & व & $\begin{array}{l}\text { Achieving this target requires developing and } \\
\text { upgrading food production and storage } \\
\text { facilities as well as upgrades in the retail } \\
\text { spaces. It also requires upgrades in energy } \\
\text { and transport infrastructure. }\end{array}$ & {$[23,32,38]$} \\
\hline 12.4 & $\begin{array}{l}\text { By } 2020 \text {, achieve the environmentally sound } \\
\text { management of chemicals and all wastes throughout } \\
\text { their life cycle, in accordance with agreed } \\
\text { international frameworks, and significantly reduce } \\
\text { their release to air, water and soil in order to } \\
\text { minimize their adverse impacts on human health and } \\
\text { the environment }\end{array}$ & & & & 0 & 口 & & $\begin{array}{l}\text { The construction and real estate sectors } \\
\text { contribute significantly to chemical } \\
\text { emissions. Adhering to best ecological and } \\
\text { environmental practices in these sectors can } \\
\text { directly help to achieve this target. }\end{array}$ & $\begin{array}{l}{[25,26,37,} \\
38]\end{array}$ \\
\hline 12.5 & $\begin{array}{l}\text { By } 2030 \text {, substantially reduce waste generation } \\
\text { through prevention, reduction, recycling and reuse }\end{array}$ & & & & 口 & & ø & Same as target 12.2 -with a focus on 4 Rs. & $\begin{array}{c}{[23,25,26,32,} \\
37,39]\end{array}$ \\
\hline 12.6 & $\begin{array}{l}\text { Encourage companies, especially large and } \\
\text { transnational companies, to adopt sustainable } \\
\text { practices and to integrate sustainability information } \\
\text { into their reporting cycle }\end{array}$ & 口 & & & & & व & $\begin{array}{l}\text { This target requires developing technology } \\
\text { infrastructure within the construction and } \\
\text { real estate sectors to increase the } \\
\text { transparency in reporting. It also requires } \\
\text { developing international sustainability } \\
\text { reporting standards within these sectors. }\end{array}$ & {$[32,39]$} \\
\hline
\end{tabular}


Table A1. Cont.

\begin{tabular}{|c|c|c|c|c|c|c|c|c|c|}
\hline & \multirow{2}{*}{ SDGs Target } & \multirow{2}{*}{$\begin{array}{l}\text { Process } \\
\text { Targets }\end{array}$} & \multicolumn{3}{|c|}{ Outcome Targets } & \multicolumn{2}{|c|}{$\begin{array}{c}\text { Dependence on } \\
\text { construction }\end{array}$} & \multirow{2}{*}{ Reason for allocation } & \multirow{2}{*}{ References } \\
\hline & & & $\begin{array}{l}\text { People- } \\
\text { centred }\end{array}$ & $\begin{array}{l}\text { Society- } \\
\text { wide }\end{array}$ & $\begin{array}{c}\text { Environ- } \\
\text { ment }\end{array}$ & Direct & Indirect & & \\
\hline 12.a & $\begin{array}{l}\text { Support developing countries to strengthen } \\
\text { their scientific and technological capacity to } \\
\text { move towards more sustainable patterns of } \\
\text { consumption and production }\end{array}$ & व & & & & & 口 & $\begin{array}{l}\text { This requires sharing know-how and best practices in } \\
\text { all industry sectors, including construction and real } \\
\text { estate. These sectors will play a key role in } \\
\text { developing, promoting and sharing mechanisms for } \\
\text { sustainable building practices. }\end{array}$ & {$[37,39]$} \\
\hline
\end{tabular}

Goal 13. Take urgent action to combat climate change and its impacts

“(...) existing buildings and settlements must be adapted to the changing conditions, including more extreme rainfalls, floods, hurricanes, drought and

Strengthen resilience and adaptive capacity

13.1 to climate-related hazards and natural disasters in all countries

Improve education, awareness-raising and

13.3 human and institutional capacity on climate change mitigation, adaptation, impact reduction and early warning heatwaves. This requires new design solutions that are resilient to the changing conditions." [39].

Achieving this target requires improving existing

buildings and infrastructure. It also requires building new facilities (such as shelters and emergency facilities) to increase the resilience of places that are vulnerable to climate-induced disasters.

Architecture, design and buildings can be used as a means to disseminate knowledge about sustainability and its practices, especially in educational, public and research facilities [106,107]. Achieving this target requires designers, real estate developers and organizations to activate this capacity in building projects. 
Table A1. Cont.

\begin{tabular}{|c|c|c|c|c|c|c|c|c|c|}
\hline & \multirow{2}{*}{ SDGs Target } & \multirow{2}{*}{$\begin{array}{l}\text { Process } \\
\text { Targets }\end{array}$} & \multicolumn{3}{|c|}{ Outcome Targets } & \multicolumn{2}{|c|}{$\begin{array}{c}\text { Dependence on } \\
\text { construction }\end{array}$} & \multirow{2}{*}{ Reason for allocation } & \multirow{2}{*}{ References } \\
\hline & & & $\begin{array}{l}\text { People- } \\
\text { centred }\end{array}$ & $\begin{array}{l}\text { Society- } \\
\text { wide }\end{array}$ & $\begin{array}{l}\text { Environ- } \\
\text { ment }\end{array}$ & Direct & Indirect & & \\
\hline 13.b & $\begin{array}{l}\text { Promote mechanisms for raising capacity for } \\
\text { effective climate change-related planning and } \\
\text { management in least developed countries and small } \\
\text { island developing States, including focusing on } \\
\text { women, youth and local and marginalized } \\
\text { communities }\end{array}$ & 口 & & & & & घ & $\begin{array}{l}\text { Same as target } 12 . a-\text { but with a focus on } \\
\text { climate change planning. }\end{array}$ & {$[37,39]$} \\
\hline \multicolumn{10}{|c|}{ Goal 14. Conserve and sustainably use the oceans, seas and marine resources for sustainable development } \\
\hline 14.2 & $\begin{array}{l}\text { By } 2020 \text {, sustainably manage and protect marine and } \\
\text { coastal ecosystems to avoid significant adverse } \\
\text { impacts, including by strengthening their resilience, } \\
\text { and take action for their restoration in order to } \\
\text { achieve healthy and productive oceans }\end{array}$ & & & & घ & ฮ & & $\begin{array}{l}\text { Construction and real estate activities are one } \\
\text { of the prime reasons (along with agriculture } \\
\text { and fisheries) for the destruction of natural } \\
\text { ecosystems [108]. Reducing the industry's } \\
\text { unsustainable practices (such as the } \\
\text { development of previously undeveloped land } \\
\text { and prime coasts) can directly help to achieve } \\
\text { this goal. }\end{array}$ & {$[34,37-40]$} \\
\hline 14.5 & $\begin{array}{l}\text { By } 2020 \text {, conserve at least } 10 \text { percent of coastal and } \\
\text { marine areas, consistent with national and } \\
\text { international law and based on the best available } \\
\text { scientific information }\end{array}$ & & & & घ & घ & & $\begin{array}{l}\text { The construction and real estate sectors-- } \\
\text { which are the main influencers in developing } \\
\text { coastal and shore sites-play a key role in } \\
\text { achieving this target. This requires not } \\
\text { accepting development and construction on } \\
\text { areas that might fall under the international } \\
\text { protection laws. "Caution must be exercised } \\
\text { when buildings or settlements are placed on the } \\
\text { coast or in fragile coastal ecosystems." [39] }\end{array}$ & {$[32,39,40]$} \\
\hline
\end{tabular}


Table A1. Cont.

\begin{tabular}{|c|c|c|c|c|c|c|c|c|c|}
\hline & \multirow{2}{*}{ SDGs Target } & \multirow{2}{*}{$\begin{array}{l}\text { Process } \\
\text { Targets }\end{array}$} & \multicolumn{3}{|c|}{ Outcome Targets } & \multicolumn{2}{|c|}{$\begin{array}{c}\text { Dependence on } \\
\text { construction }\end{array}$} & \multirow{2}{*}{ Reason for allocation } & \multirow{2}{*}{ References } \\
\hline & & & $\begin{array}{l}\text { People- } \\
\text { centred }\end{array}$ & $\begin{array}{l}\text { Society- } \\
\text { wide }\end{array}$ & $\begin{array}{c}\text { Environ- } \\
\text { ment }\end{array}$ & Direct & Indirect & & \\
\hline 14.7 & $\begin{array}{l}\text { By 2030, increase the economic benefits to small } \\
\text { island developing States and least developed } \\
\text { countries from the sustainable use of marine } \\
\text { resources, including through sustainable } \\
\text { management of fisheries, aquaculture and tourism }\end{array}$ & & & 0 & & & 0 & $\begin{array}{l}\text { Real estate development activities-especially } \\
\text { related to tourism—could play a supporting } \\
\text { role in achieving this target. It requires } \\
\text { focusing on development in small island } \\
\text { states and developing counties through } \\
\text { nature-based tourism. Also, this requires } \\
\text { focusing on "waste and wastewater treatment, } \\
\text { for example during the construction and use } \\
\text { stages of hotels" [38]. }\end{array}$ & {$[32,38,40]$} \\
\hline 14.b & $\begin{array}{l}\text { Provide access for small-scale artisanal fishers to } \\
\text { marine resources and markets }\end{array}$ & 口 & & & & & ø & $\begin{array}{l}\text { Requires building and developing or } \\
\text { transmitting the know-how for establishing } \\
\text { small scale fisheries. It also requires } \\
\text { expanding the infrastructure for markets and } \\
\text { transport infrastructure. }\end{array}$ & \\
\hline \multicolumn{10}{|c|}{$\begin{array}{l}\text { Goal 15. Protect, restore and promote sustainable use of terrestrial ecosystems, sustainably manage forests, } \\
\text { combat desertification, and halt and reverse land degradation and halt biodiversity loss }\end{array}$} \\
\hline 15.1 & $\begin{array}{l}\text { By } 2020 \text {, ensure the conservation, restoration and } \\
\text { sustainable use of terrestrial and inland freshwater } \\
\text { ecosystems and their services, in particular forests, } \\
\text { wetlands, mountains and drylands, in line with } \\
\text { obligations under international agreements }\end{array}$ & & & & 口 & व & & $\begin{array}{l}\text { Like target } 14.2 \text { but focused on terrestrial } \\
\text { ecosystems. }\end{array}$ & {$[34,37-40]$} \\
\hline
\end{tabular}


Table A1. Cont.

\begin{tabular}{|c|c|c|c|c|c|c|c|c|c|}
\hline & \multirow{2}{*}{ SDGs Target } & \multirow{2}{*}{$\begin{array}{l}\text { Process } \\
\text { Targets }\end{array}$} & \multicolumn{3}{|c|}{ Outcome Targets } & \multicolumn{2}{|c|}{$\begin{array}{c}\text { Dependence on } \\
\text { construction }\end{array}$} & \multirow{2}{*}{ Reason for allocation } & \multirow{2}{*}{ References } \\
\hline & & & $\begin{array}{l}\text { People- } \\
\text { centred }\end{array}$ & $\begin{array}{l}\text { Society- } \\
\text { wide }\end{array}$ & $\begin{array}{c}\text { Environ- } \\
\text { ment }\end{array}$ & Direct & Indirect & & \\
\hline 15.2 & $\begin{array}{l}\text { By 2020, promote the implementation of } \\
\text { sustainable management of all types of forests, } \\
\text { halt deforestation, restore degraded forests and } \\
\text { substantially increase afforestation and } \\
\text { reforestation globally }\end{array}$ & & & & o & & 口 & $\begin{array}{l}\text { Adopting regulations and standards and } \\
\text { certifications in construction (such as FSC) to ensure } \\
\text { the sustainable management of forests as well as the } \\
\text { use of materials that reduce the pressure on forests. } \\
\text { Responsible real estate investment strategies to } \\
\text { protect forests could also be used [109]. Strategies in } \\
\text { the real estate sector could include natural } \\
\text { preservation for prime forests. }\end{array}$ & {$[38,39]$} \\
\hline 15.3 & $\begin{array}{l}\text { By 2030, combat desertification, restore } \\
\text { degraded land and soil, including land affected } \\
\text { by desertification, drought and floods, and } \\
\text { strive to achieve a land degradation-neutral } \\
\text { world }\end{array}$ & & & & o & 口 & & $\begin{array}{l}\text { Construction activities are one of the leading causes } \\
\text { of the degradation of agricultural land and } \\
\text { terrestrial ecosystems [110]. "Ecosystems and } \\
\text { biodiversity are under intense pressure due to } \\
\text { growing cities and settlements, farming, mining and }\end{array}$ & \\
\hline 15.4 & $\begin{array}{l}\text { By } 2030 \text {, ensure the conservation of mountain } \\
\text { ecosystems, including their biodiversity, in } \\
\text { order to enhance their capacity to provide } \\
\text { benefits that are essential for sustainable } \\
\text { development }\end{array}$ & & & & ㅇ & 口 & & $\begin{array}{l}\text { the changing climate. To protect, restore and support } \\
\text { ecosystems and biodiversity, buildings and } \\
\text { settlements must include habitats for plants, insects } \\
\text { and animals. This means that green-field } \\
\text { developments should be kept to a minimum and that }\end{array}$ & {$[25,37-40]$} \\
\hline 15.5 & $\begin{array}{l}\text { Take urgent and significant action to reduce the } \\
\text { degradation of natural habitats, halt the loss of } \\
\text { biodiversity and, by 2020, protect and prevent } \\
\text { the extinction of threatened species }\end{array}$ & 口 & & & & o & & $\begin{array}{l}\text { planning and development of all new settlements } \\
\text { must ensure sustainable conditions for local } \\
\text { ecosystems, flora and fauna.” [39] } \\
\text { Achieving these targets directly requires changes in } \\
\text { construction and real estate practices that focus on } \\
\text { preservation and, when possible, restoration. }\end{array}$ & \\
\hline
\end{tabular}


Table A1. Cont.

\begin{tabular}{|c|c|c|c|c|c|c|c|c|c|}
\hline & \multirow{2}{*}{ SDGs Target } & \multirow{2}{*}{$\begin{array}{l}\text { Process } \\
\text { Targets }\end{array}$} & \multicolumn{3}{|c|}{ Outcome Targets } & \multicolumn{2}{|c|}{$\begin{array}{l}\text { Dependence on } \\
\text { construction }\end{array}$} & \multirow{2}{*}{ Reason for allocation } & \multirow{2}{*}{ References } \\
\hline & & & $\begin{array}{l}\text { People- } \\
\text { centred }\end{array}$ & $\begin{array}{l}\text { Society- } \\
\text { wide }\end{array}$ & $\begin{array}{c}\text { Environ- } \\
\text { ment }\end{array}$ & Direct & Indirect & & \\
\hline 15.9 & $\begin{array}{l}\text { By 2020, integrate ecosystem and } \\
\text { biodiversity values into national and local } \\
\text { planning, development processes, poverty } \\
\text { reduction strategies and accounts }\end{array}$ & & & व & & & 口 & $\begin{array}{l}\text { Establishing and implementing best practices in the } \\
\text { construction and real estate sectors as well as } \\
\text { integrating sustainability principles in the real estate } \\
\text { sector [46]. }\end{array}$ & {$[25,40]$} \\
\hline \multicolumn{10}{|c|}{$\begin{array}{l}\text { Goal 16. Promote peaceful and inclusive societies for sustainable development, provide access to } \\
\text { justice for all and build effective, accountable and inclusive institutions at all levels }\end{array}$} \\
\hline 16.6 & $\begin{array}{l}\text { Develop effective, accountable and } \\
\text { transparent institutions at all levels }\end{array}$ & & & ఠ & & & व & $\begin{array}{l}\text { "To support society's expression of its values through } \\
\text { buildings and public space, architecture and planning } \\
\text { must ensure that public spaces and institutions are } \\
\text { inclusive, welcoming, secure and non-discriminatory. (...) } \\
\text { The design of libraries, community centers, safe houses } \\
\text { and places of worship must ensure safety, inclusiveness } \\
\text { and affordability”. This could require new facilities as } \\
\text { well as improvements (energy and networks) in existing } \\
\text { spaces. }\end{array}$ & {$[32,39,40]$} \\
\hline \multicolumn{10}{|c|}{$\begin{array}{l}\text { Goal 17. Strengthen the means of implementation and revitalize the Global Partnership for } \\
\text { Sustainable Development }\end{array}$} \\
\hline \multicolumn{10}{|c|}{ Technology } \\
\hline 17.7 & $\begin{array}{l}\text { Promote the development, transfer, } \\
\text { dissemination and diffusion of } \\
\text { environmentally sound technologies to } \\
\text { developing countries on favourable } \\
\text { terms, including on concessional and } \\
\text { preferential terms, as mutually agreed }\end{array}$ & 口 & & & & & 口 & $\begin{array}{l}\text { "Architects, designers and planners can contribute by } \\
\text { sharing knowledge, promoting sustainable solutions and } \\
\text { engage in collaboration with research and institutional } \\
\text { partners, to develop and implement sustainable } \\
\text { solutions.” [39] }\end{array}$ & {$[39,40]$} \\
\hline
\end{tabular}


Table A1. Cont.

\begin{tabular}{|c|c|c|c|c|c|c|c|c|}
\hline \multirow{2}{*}{ SDGs Target } & \multirow{2}{*}{$\begin{array}{l}\text { Process } \\
\text { Targets }\end{array}$} & \multicolumn{3}{|c|}{ Outcome Targets } & \multicolumn{2}{|c|}{$\begin{array}{c}\text { Dependence on } \\
\text { construction }\end{array}$} & \multirow{2}{*}{ Reason for allocation } & \multirow{2}{*}{ References } \\
\hline & & $\begin{array}{l}\text { People- } \\
\text { centred }\end{array}$ & $\begin{array}{l}\text { Society- } \\
\text { wide }\end{array}$ & $\begin{array}{c}\text { Environ- } \\
\text { ment }\end{array}$ & Direct & Indirect & & \\
\hline
\end{tabular}

Fully operationalize the technology bank and

science, technology and innovation capacity-

17.8

building mechanism for least developed countries

by 2017 and enhance the use of enabling

technology, in particular information and

Requires expanding available ICT

communications technology

\section{Capacity-building}

Enhance international support for implementing effective and targeted capacity-building in

17.9 developing countries to support national plans to implement all the Sustainable Development Goals, including through North-South, South-South and triangular cooperation

technologies and infrastructure to enable the

creation of knowledge databases. 


\section{REFERENCES}

1. Yudelson J. The Green Building Revolution. Washington, D.C. (US): Island Press; 2008.

2. Brandon PS, Lombardi P. Evaluating Sustainable Development in the Built Environment. 2nd ed. Chichester, West Sussex (UK): Blackwell Publishing Ltd; 2011.

3. Guinée J. Life Cycle Sustainability Assessment: What Is It and What Are Its Challenges? In: Clift R, Druckman A, editors. Taking Stock of Industrial Ecology. Cham (Switzerland): Springer Open; 2016. p. 45-68.

4. Parent J, Cucuzzella C, Revéret JP. Impact assessment in SLCA: Sorting the sLCIA methods according to their outcomes. Int J Life Cycle Assess. 2010;15(2):164-71.

5. Ding GKC. Sustainable construction-The role of environmental assessment tools. J Environ Manage. 2008;86(3):451-64.

6. Bernardi E, Carlucci S, Cornaro C, Bohne R. An Analysis of the Most Adopted Rating Systems for Assessing the Environmental Impact of Buildings. Sustainability. 2017;9(7):1226.

7. Bragança L, Mateus R, Koukkari H. Building sustainability assessment. Sustainability. 2010;2(7):2010-23.

8. United Nations. Transforming our world: The 2030 agenda for sustainable development. New York (US): United Nations; 2015.

9. Lynch AJ, Mosbah SM. Improving local measures of sustainability: A study of built-environment indicators in the United States. Cities. 2017;60:301-13.

10. Valdes-Vasquez R, Klotz LE. Social Sustainability Considerations during Planning and Design: Framework of Processes for Construction Projects. J Constr Eng Manag. 2013;139(1):80-9.

11. Goubran S, Emond G, Cucuzzella C. Understanding Regional Sustainability in the Built Environment. The 2nd ARTEM Organisational Creativity and Sustainability International Conference; 2017 Sep 14-16; Nancy, France.

12. James P. Urban Sustainability in Theory and Practice. New York (US): Routledge; 2014.

13. Pedersen CS. The UN Sustainable Development Goals (SDGs) are a Great Gift to Business! Procedia CIRP. 2018;69:21-4.

14. Goubran S, Masson T, Caycedo M. Evolutions in Sustainability and Sustainable Real Estate. In: Walker T, Krosinsky C, Hasan LN, Kibsey SD, editors. Sustainable Real Estate. Cham (Switzerland): Palgrave Macmillan; 2019. p. 1131.

15. Allen C, Metternicht G, Wiedmann T. Initial progress in implementing the Sustainable Development Goals (SDGs): a review of evidence from countries. Sustain Sci. 2018;13(5):1453-67.

16. Nilsson M, Chisholm E, Griggs D, Howden-Chapman P, McCollum D, Messerli $\mathrm{P}$, et al. Mapping interactions between the sustainable development goals: lessons learned and ways forward. Sustain Sci. 2018;13(6):1489-503.

17. Lafortune G, Fuller G, Moreno J, Schmidt-traub G, Kroll C. SDG Index and Dashboards-Detailed Methodological paper. New York (US): SDSN; 2018. 
18. Diaz-Sarachaga JM, Jato-Espino D, Castro-Fresno D. Is the Sustainable Development Goals (SDG) index an adequate framework to measure the progress of the 2030 Agenda? Sustain Dev. 2018;26(6):663-71.

19. Le Blanc D. Towards integration at last? The sustainable development goals as a network of targets. DESA Working Paper. New York (US): UN DESA; 2015. Report No.: ST/ESA/2015/DWP/141.

20. Allen C, Metternicht G, Wiedmann T. Prioritising SDG targets: assessing baselines, gaps and interlinkages. Sustain Sci. 2019;14(2):421-38.

21. Lior N, Radovanović M, Filipović S. Comparing sustainable development measurement based on different priorities: sustainable development goals, economics, and human well-being-Southeast Europe case. Sustain Sci. 2018;13(4):973-1000.

22. Salvia AL, Leal Filho W, Brandli LL, Griebeler JS. Assessing research trends related to Sustainable Development Goals: local and global issues. J Clean Prod. 2019;208:841-9.

23. Santika WG, Anisuzzaman M, Bahri PA, Shafiullah GM, Rupf GV, Urmee T. From goals to joules: A quantitative approach of interlinkages between energy and the Sustainable Development Goals. Energy Res Soc Sci. 2018;50:201-14.

24. Nunes AR, Lee K, O’Riordan T. The importance of an integrating framework for achieving the Sustainable Development Goals: The example of health and well-being. BMJ Glob Heal. 2016;1:e000068.

25. Alawneh R, Ghazali F, Ali H, Sadullah AF. A Novel framework for integrating United Nations Sustainable Development Goals into sustainable nonresidential building assessment and management in Jordan. Sustain Cities Soc. 2019;49:101612.

26. Alawneh R, Mohamed Ghazali FE, Ali H, Asif M. Assessing the contribution of water and energy efficiency in green buildings to achieve United Nations Sustainable Development Goals in Jordan. Build Environ. 2018;146:119-32.

27. Gibberd J. Measuring capability for sustainability: the Built Environment Sustainability Tool (BEST). Build Res Inf. 2015;43(1):49-61.

28. Eizenberg E, Jabareen Y. Social Sustainability: A New Conceptual Framework. Sustainability. 2017;9(1):68.

29. The World Business Council for Sustainable Development (WBCSD). SDG Sector Roadmaps. Geneva (Switzerland): WBCSD; 2018.

30. Hsieh H-F, Shannon SE. Three Approaches to Qualitative Content Analysis. Qual Health Res. 2005;15(9):1277-88.

31. Behm M. Construction Sector. J Safety Res. 2008;39(2):175-8.

32. McCollum D, Gomez Echeverri L, Krey V, Rogelj J, Nilsson M, Busch S, et al. Connecting the sustainable development goals by their energy inter-linkages. Environ Res Lett. 2018;13:033006.

33. The Economist Intelligence Unit. The critical role of infrastructure for the Sustainable Development Goals. London (UK): The Economist Intelligence Unit; 2019. 
34. United Nations. Annex: Global Indicator Framework for the Sustainable Development Goals and Targets of the 2030 Agenda for Sustainable Development. Work of the Statistical Commission pertaining to the 2030 Agenda for Sustainable Development. New York (US): United Nations; 2017. A/RES/71/313.

35. Tjoa AM, Tjoa S. The Role of ICT to Achieve the UN Sustainable Development Goals (SDG). In: Mata FJ, Pont A, editors. ICT for Promoting Human Development and Protecting the Environment. Cham (Switzerland): Springer International Publishing; 2016. p. 3-13.

36. Engberg-Pedersen P, Zwart R. The 2030 Agenda and Development Cooperation Results. Paris (France): OECD; 2018.

37. Government of Canada. Canada's Implementation of the 2030 Agenda for Sustainable Development-Voluntary National Review. Ottawa (Canada): Government of Canada; 2018.

38. GRI; PWC; UN Global Compact. Business Reporting on the SDGs: An Analysis of Goals and Targets. New York (US): GRI \& UN Global Compact; 2018.

39. Mossin N, Stilling S, Bøjstrup TC, Larsen VG, Lotz M, Blegvad A, editors. An architecture guide to the UN 17 Sustainable Development Goals. Copenhagen (Denmark): KADK; 2018.

40. Maes MJA, Jones KE, Toledano MB, Milligan B. Mapping synergies and tradeoffs between urban ecosystems and the sustainable development goals. Environ Sci Policy. 2019;93:181-8.

41. Engberg-Pedersen P. An SDG-based results framework for development cooperation-Draft Note by the Results Team of the Development Co-operation Directorate Paris, January 2016. Paris (France): OECD; 2016.

42. Ehrenfeld JR. Sustainability by Design: A Subversive Strategy for Transforming Our Consumer Culture. New Haven (US): Yale University Press; 2009.

43. Moore SA, Engstrom N. The social construction of "green building" codes: Competing models by industry, government and NGOs. In: Sustainable Architectures: Critical Explorations of Green Building Practice in Europe and North America. New York (US): Spon Press Taylor \& Francis Group; 2004. p. 51-70.

44. IPCC. Climate Change 2014: Mitigation of Climate Change. Summary for Policymakers and Technical Summary. Climate Change 2014: Mitigation of Climate Change. Part of the Working Group III Contribution to the Fifth Assessment Report of the Intergovernmental Panel on Climate Change. Geneva (Switzerland): IPCC; 2014.

45. World Economic Forum; The Boston Consulting Group. Shaping the Future of Construction: A Breakthrough in Mindset and Technology. Cologny (Switzerland): World Economic Forum; 2016.

46. World Economic Forum. Environmental Sustainability Principles for the Real Estate Industry. Cologny (Switzerland): World Economic Forum; 2016.

47. Lawrence M. Reducing the Environmental Impact of Construction by Using Renewable Materials. J Renew Mater. 2015;3(3):163-74. 
48. Rashid AFA, Yusoff S. A review of life cycle assessment method for building industry. Renew Sustain Energy Rev. 2015;45:244-8.

49. Willmott Dixon. Briefing Note 33: The Impacts of Construction and the Built Environment. Letchworth (UK): Willmott Dixon; 2010.

50. Department of Economic and Social Affairs Population Division. World Urbanization Prospects The 2014 Revision. New York (US): United Nations; 2014. p. 517.

51. PwC. Real Estate 2020 Building the future. New York (US): PwC; 2014.

52. Marketline. Global Construction \& Engineering. London (UK): Marketline; 2017.

53. Jones SA, Laquidara-Carr D, editors. World Green Building Trends 2018Smart market report. Bedford (US): Dodge Data \& Analytics; 2018. p. 80.

54. World Economic Forum; The Boston Consulting Group. Future Scenarios and Implications for the Industry. Cologny (Switzerland): World Economic Forum; 2018.

55. Henderson R. Making the Business Case for Environmental Sustainability. In: Henderson R, Gulati R, Tushman M, editors. Leading Sustainable Change: An Organizational Perspective. Oxford (UK): Oxford University Press; 2015. p. 23-45.

56. Oxford Economics; PwC. Capital project and infrastructure spendingOutlook to 2025. New York (US): PwC; 2014.

57. Global Construction Perspectives; Oxford Economics. Global Construction 2030-A global forecast for the construction industry to 2030. London (UK): Global Construction Perspectives and Oxford Economics; 2015.

58. Woetzel J, Garemo N, Mischke J, Kamra P, Palter R. Bridging infrastructure gaps: Has the world made progress? New York (US): McKinsey \& Company; 2017.

59. Maywald C, Riesser F. Sustainability-The Art of Modern Architecture. Procedia Eng. 2016;155:238-48.

60. Pocock J, Steckler C, Hanzalova B. Improving Socially Sustainable Design and Construction in Developing Countries. Procedia Eng. 2016;145:288-95.

61. Magala S. Business as unusual. Nat Energy. 2017;2(9):17150.

62. Dyllick T, Muff K. Clarifying the Meaning of Sustainable Business: Introducing a Typology from Business-as-Usual to True Business Sustainability. Organ Environ. 2015;29(2):156-74.

63. Cucuzzella C. Creativity, sustainable design and risk management. J Clean Prod. 2016;135:1548-58.

64. Vefago LHM, Avellaneda J. The Unsustainability of Sustainable Architecture. In: 18th CIB World Building Congress W096-Architectural Management. Salford (UK): International Concil for Research and Innovation in Building and Construction; 2010. p. 212-23.

65. Naess A. The shallow and the deep, long-range ecology movement. A summary. Inquiry. 2008;16(1-4):95-100.

66. Brown M. Futurestorative: working towards a new sustainability. London (UK): RIBA Publishing; 2016. 
67. DLA Piper. Towards a Greener Future-DLA Piper's market report on sustainable real estate. Chicago (US): DLA Piper; 2014.

68. Bon R, Hutchinson K. Sustainable construction: Some economic challenges. Build Res Inf. 2010;28(5-6):310-4.

69. Cucuzzella C. Why is fourth generation evaluation essential for sustainable design? Des Princ Pract. 2011;5(1):239-51.

70. Cucuzzella C. The normative turn in environmental architecture. J Clean Prod. 2019;219:552-65.

71. Dissou Y, Siddiqui MS. Can carbon taxes be progressive? Energy Econ. 2014;42:88-100.

72. Murray B, Rivers N. British Columbia’s revenue-neutral carbon tax: A review of the latest "grand experiment" in environmental policy. Energy Policy. 2015;86:674-83.

73. Gusmão Caiado RG, Leal Filho W, Quelhas OLG, Luiz de Mattos Nascimento D, Ávila LV. A literature-based review on potentials and constraints in the implementation of the sustainable development goals. J Clean Prod. 2018;198:1276-88.

74. United Nations. The Future We Want. Our Common Vision. Rio20 United Nations Conference on Sustainable Development; 2012 Jun 20-22; Rio de Janeiro, Brazil. New York (US): United Nations; 2012.

75. Gupta J, Vegelin C. Sustainable development goals and inclusive development. Int Environ Agreements Polit Law Econ. 2016;16(3):433-48.

76. Jayasooria D. Sustainable Development Goals and Social Work: Opportunities and Challenges for Social Work Practice in Malaysia. J Hum Rights Soc Work. 2016;1(1):19-29.

77. Moyer JD, Bohl DK. Alternative pathways to human development: Assessing trade-offs and synergies in achieving the Sustainable Development Goals. Futures. 2018;105:199-210.

78. Wysokińska Z. Millenium Development Goals/UN and Sustainable Development Goals/UN as Instruments for Realising Sustainable Development Concept in the Global Economy. Comp Econ Res. 2017;20(1): 101-18.

79. Bojer M. What If We Really Meant It? Transformative approaches for the Sustainable Development Goals. Reos Partners Blog. Geneva (Switzerland): Reos Partners; 2017.

80. Carant JB. Unheard voices: a critical discourse analysis of the Millennium Development Goals' evolution into the Sustainable Development Goals. Third World Q. 2015;38(1):16-41.

81. Corporate Citizenship; Business \& Sustainable Development Commission. SDGs \& Sectors: A review of the business opportunities. London (UK): Corporate Citizenship; 2016.

82. The Oslo Manifesto: Design and Architecture for the SDGs. The Oslo Manifesto. 2015. Available from: http://oslomanifesto.org/. Accessed 2018 Sep 6.

83. Cucuzzella C. Is Sustainability Reorienting the Visual Expression of Architecture? RACAR Rev d'art Can. 2015;40(2):86-100. 
84. De Gregorio S. From Kyoto to Paris: searching the sustainability. Vitr. Int J Archit Technol Sustain. 2016;1(1):VII.

85. Liu L, Huang CZ, Huang G, Baetz B, Pittendrigh SM. How a carbon tax will affect an emission-intensive economy: A case study of the Province of Saskatchewan, Canada. Energy. 2018;159:817-26.

86. Di Foggia G. Energy efficiency measures in buildings for achieving sustainable development goals. Heliyon. 2018;4(11):e00953.

87. Cole RJ. Building environmental assessment methods: redefining intentions and roles. Build Res Inf. 2005;33(5):455-67.

88. Cucuzzella C. When the Narrative of Environmental Certifications Replaces the Debate on Quality. In: Faire des histoires? Du récit d'urbanisme à l'urbanisme fictionnel: faire la ville à l'heure de la société du spectacle. Geneve (Switzerland): Fondation Braillard Architectes; 2015. p. 43-7. French.

89. Schweber L. Jack-in-the-black-box: Using Foucault to explore the embeddedness and reach of building level assessment methods. Energy Res Soc Sci. 2017;34:294-304.

90. USGB Council. LEED v4 Building Design and Construction. Washington, D.C. (US): USGB Council; 2014.

91. Díaz-López C, Carpio M, Martín-Morales M, Zamorano M. Analysis of the scientific evolution of sustainable building assessment methods. Sustain Cities Soc. 2019;49:101610.

92. Illankoon IMCS, Tam VWY, Le KN, Shen L. Key credit criteria among international green building rating tools. J Clean Prod. 2017;164:209-20.

93. Alyami SH, Rezgui Y. Sustainable building assessment tool development approach. Sustain Cities Soc. 2012;5(1):52-62.

94. Kylili A, Fokaides PA, Jimenez PAL. Key Performance Indicators (KPIs) approach in buildings renovation for the sustainability of the built environment: A review. Renew Sustain Energy Rev. 2016;56:906-15.

95. Czerwinska D. Green building: Improving the lives of billions by helping to achieve the UN Sustainable Development Goal. Green building \& the Sustainable Development Goals. 2017. Available from: https://www.worldgbc.org/green-building-sustainable-development-goals. Accessed 2019 Jun 3.

96. Goubran S, Cucuzzella C. Integrating the Sustainable Development Goals in Building Projects. J Sustain Res. 2019;1:e190010.

97. Sustainable Development Solutions Network (SDSN). SDGs Index and Dashboard Report 2018: Global Responsibilites: Implementing the Goals. New York (US): SDSN; 2018.

98. Wackernagel M, Hanscom L, Lin D. Making the Sustainable Development Goals Consistent with Sustainability. Front Energy Res. 2017;5:1-5.

99. Cucuzzella C, Hammond CI, Goubran S, Lalonde C, editors. Du Didactisme en Architecture/On Didacticism in Architecture. Vol. 3, Cahiers de Recherche du LEAP. Montreal (Canada): Potential Architecture Books; 2019. French.

100. Cucuzzella C. Eco-Didactic Design in the Public Realm. Presented at: Sustainable City, 13th International Conference on Urban Regeneration and Sustainability; 2019 Oct 1-3; Valencia, Spain. 
101. Sheth S, Mahajan S, editors. Breakthrough for sustainability in commercial real estate. New York (US): Deloitte; 2014.

102. UN Global Compact; UNEP; Oxfam; Word Resource Institute. Adapting for a Green Economy: Companies, Communities and Climate Change. A Caring for Climate Report. New York (US): UN Global Compact; 2011.

103. Blombäck P, Poschen P. Decent work in forestry? Enhancing forestry work and forest-based livelihoods. In: XII World Forestry Congress Proceedings. Quebec City (Canada): Food and Agriculture Organization of the United Nations; 2003. p. 231-40.

104. Jørgensen RB. Sorption of VOCs on material surfaces as the deciding factor when choosing a ventilation strategy. Build Environ. 2007;42:1913-20.

105. Gholitabar S, Alipour H, Costa C. An Empirical Investigation of Architectural Heritage Management Implications for Tourism: The Case of Portugal. Sustainability. 2018;10(2):93.

106. Chansomsak S, Vale B. Can Architecture Really Educate People For Sustainability. In: Foliente G, Luetzkendorf T, Newton P, Paevere P, editors. Proceedings of the 2008 World Sustainable Building Conference. Melbourne (Australia): Melbourne Convention Centre; 2008.

107. Cole LB. The Teaching Green School Building: a framework for linking architecture and environmental education. Environ Educ Res. 2014;20(6):83657.

108. Lira PK, Tambosi LR, Ewers RM, Metzger JP. Land-use and land-cover change in Atlantic Forest landscapes. For Ecol Manage. 2012;278:80-9.

109. Goubran S, Masson T, Walker T. Diagnosing the local suitability of high-rise timber construction. Build Res Inf. 2019;48(1):101-23.

110. Kalnay E, Cai M. Impact of urbanization and land-use change on climate. Nature. 2003;423(6939):528-31.

How to cite this article:

Goubran S. On the Role of Construction in Achieving the SDGs. J Sustain Res. 2019;1:e190020. https://doi.org/10.20900/jsr20190020 